CDD: 170

\title{
A RELAÇÃO ENTRE ÉTICA E DIREITO NA FILOSO- FIA POLÍTICA DE KANT
}

\author{
JOEL KLEIN \\ Universidade Federal do Rio Grande do Norte (UFRN) \\ Brasil \\ jthklein@yahoo.com.br
}

Received: 17.06.20 I3; Revised: 25.02.20I4; Accepted: 03.04.20 I4

\begin{abstract}
This article discusses the relationship between law and ethics in Kantian political philosophy. Unlike the dominant interpretation, I attempt to show that, in order for politics to achieve its goals, good will must be present. Two theses are defended here: first, that there is no gap between the political theses of the 1780s and those of the 1790s regarding an abandonment of the need for good will in the field of politics, i.e., the good will still remains a necessary condition for carrying out a republican constitution. Against an exclusively liberal interpretation, the second thesis argues that Kantian republicanism allows the state to take institutional measures to ensure the moral enlightenment of its citizens.
\end{abstract}

Key-words: Kant, good will, politics, history, moral education

Resumo: Este artigo discute as relações existentes entre direito e ética na filosofia política kantiana e, ao contrário da interpretação dominante, procura mostrar que a boa vontade precisa estar presente para que a política possa alcançar plenamente seus objetivos. Nesse sentido, defendese aqui duas teses: primeira, que não há uma ruptura das teses políticas da década de oitenta com as teses políticas da década de noventa no sentido de um abandono da necessidade de uma boa vontade no campo da política, a qual é condição necessária para a realização de uma constituição republicana; segunda, contra uma interpretação exclusivamente liberal, defende-se que isso implica que o republicanismo kantiano permite que o Estado assuma medidas institucionais para um esclarecimento moral de seus cidadãos.

Manuscrito - Rev. Int. Fil., Campinas, v. 37 , n. 1, p. 165 - 221, jan.-jun. 2014. 
Palavras chave: Kant, boa vontade, política, história, educação

\section{INTRODUÇÃO}

No intuito de mostrar que na filosofia histórico-política kantiana há uma continuidade da tese sobre o desenvolvimento moral dos indivíduos como condição para o progresso políticojurídico, as duas primeiras partes deste artigo reconstroem tanto a posição kantiana apresentada na década de oitenta, quanto na década de noventa. Nesse sentido, na primeira seção analisa-se o texto Ideia de uma história universal com um propósito cosmopolita de 1784, enquanto que a segunda seção investiga prioritariamente o ensaio $\grave{A}$ paz perpétua de 1795. Pressupondo as seções anteriores, a terceira seção mostra como a filosofia histórico-política kantiana aponta para a legitimidade da atuação do Estado na formação moral de seus cidadãos, mais especificamente no ensino público da virtude, uma leitura que vai de encontro a uma concepção estritamente liberal da política kantiana. Finalmente, na última seção, discute-se o status teórico que essa virtude moral, enquanto fim almejado da educação pública, possui internamente ao sistema da filosofia prática kantiana.

\section{O PROBLEMA DO LENHO RETORCIDO}

Para compreender a relação existente entre a boa vontade e a política, entre a ética e a doutrina aplicada do direito é preciso responder à seguinte questão: é preciso que os indivíduos também se desenvolvam moralmente para que um Estado possa se aproximar constantemente de uma constituição republicana perfeita? Ora, por mais que Kant se utilize da tese do antagonismo das disposições humanas, isto é, da tese da sociabilidade insociável como uma artimanha da Natureza para fazer progredir a cultura e

Manuscrito - Rev. Int. Fil., Campinas, v. 37 , n. 1, p. 165 - 221, jan.-jun. 2014. 
evitar a indolência humana (Cf. Klein, 2013a), ${ }^{1}$ ele também indicou claramente que essa não pode ser a solução única e última para o progresso das disposições da espécie humana. Não se pode jamais esquecer que se está falando de seres livres e de que o progresso político precisa ser também fruto de uma escolha. ${ }^{2}$ É esse o problema que a sexta proposição da $\mathrm{Ia} G$ têm em vista:

O homem é um animal que, quando vive entre os seus congêneres, precisa de um senhor. Com efeito, abusa certamente da sua liberdade em relação aos outros semelhantes; e, embora, como criatura racional, deseja uma lei que ponha limites à liberdade de todos, a sua animal tendência egoísta desencaminha-o, no entanto, onde ele tem que renunciar a si mesmo. Necessita, pois, de um

${ }^{1}$ Todas as obras de Kant serão citadas segundo a Akademie Ausgabe. Por exemplo: " $I a G$, AA 08: 23 ", sendo " $I a G$ " a sigla que indica o nome da obra em alemão (nesse caso, ver a bibliografia para conferir as siglas), depois "AA 08" significando o volume oitavo da edição da academia, e, em seguida, o número da página. As letras "f" e "ff" Significam página(s) seguinte(s). A letra "n" significa "nota de rodapé". Nas citações, itálicos são de Kant e os negritos são meus.

${ }^{2}$ Kant indica claramente que a história é fruto do agir livre dos indivíduos na terceira proposição da IaG: "A Natureza quis que o homem tire totalmente de si tudo o que ultrapassa o arranjo mecânico da sua existência animal, e que não participe de nenhuma outra felicidade ou perfeição exceto a que ele conseguiu por si mesmo, liberto do instinto, através da própria razão. (...) Parece que a Natureza se comprazeu aqui na sua máxima parcimônia e que mediu com tanta concisão o seu equipamento animal e de moto tão ajustado à máxima necessidade de uma existência incipiente como se quisesse que o homem, se alguma vez houvesse de passar da maior rudez à máxima destreza, à perfeição interna do seu pensar e, assim (tanto quanto possível na terra), à felicidade, fosse o único a disso ter o mérito e apenas a si estar agradecido; como se a ela importasse mais a sua autoestima racional do que qualquer bem estar." (IaG, AA 08: 19f.). Liberdade entende-se aqui a liberdade do arbítrio e não a liberdade da vontade. Sobre essa diferença conferir MS, AA 06: $213 f$.

Manuscrito - Rev. Int. Fil., Campinas, v. 37 , n. 1, p. 165 - 221, jan.jun. 2014. 
senhor que lhe quebrante a própria vontade e o force a obedecer uma vontade universalmente válida, e possa no entanto ser livre. Mas onde vai ele buscar tal senhor? A nenhures, a não ser no gênero humano. (IaG, AA 08: 23)

Visto que o progresso depende de escolhas como aquela de seguir ou não as leis do Estado, surge a questão de se ainda é possível oferecer uma garantia para o progresso, pois, finalmente, o progresso acaba em algum momento dependendo de uma escolha, de uma decisão livre. Da mesma forma que todos os outros indivíduos, o legislador, na figura do "senhor", tem a tendência a abusar de sua liberdade, abrindo para si uma exceção na lei. Para que não haja um regresso ao infinito e para que de fato haja a possibilidade de um progresso em direção à instituição de uma sociedade perfeitamente justa, onde as disposições dos indivíduos possam de fato encontrar as condições para florescer convenientemente, faz-se necessário que, em algum momento, os indivíduos se esclareçam moralmente. Por isso Kant termina a sexta proposição enumerando três condições necessárias para se resolver o problema mais difícil (das schwerste) do gênero humano: primeiro, possuir os conceitos corretos da natureza da constituição; segundo, ter uma experiência muito desenvolvida sobre o curso do mundo; em terceiro lugar e sobretudo, possuir uma boa vontade disposta a aceitá-la (Cf. Ia G, AA 08: 23).

Mas por que o problema do legislador moralmente esclarecido é o mais difícil, sendo até mesmo sua solução perfeita impossível? A resposta de Kant: "de um lenho tão retorcido, de que o homem é feito, nada de inteiramente reto se pode fazer. Apenas uma aproximação a esta ideia nos é imposta pela Natureza”. Essa metáfora do lenho retorcido é a segunda metáfora botânica que Kant utiliza na $I a G$. Se na metáfora do bosque se tratava de pensar numa situação em que as árvores pudessem crescer retas, agora se tem a afirmação de que a árvore humana já está demasiado 
retorcida. Assim, como no caso da sociabilidade insociável, essa tese de que o gênero humano já se encontra retorcido possui o status de uma constatação antropológica. Uma floresta que não começa como tal, mas pela aproximação gradual de árvores esparsas é uma floresta onde as árvores já estão retorcidas. Se, no caso da floresta um impulso gradual conduz ao crescimento reto das árvores, no caso dos homens, trata-se de um impulso intencional e voluntário (Cf. Guyer, 2009,132). Por isso, Pinzani sugere que essa relação seria melhor caracterizada pela metáfora de um jardineiro ao invés da analogia do bosque. Nesse caso, o legislador, assim como o jardineiro, cuidaria para que as plantas crescessem belas, seja podando-as, seja limpando os canteiros das ervas daninhas (Cf. Pinzani, 2011, 71). Mas nesse caso, ainda permanece o problema de que "não se tem como prever de que forma o gênero humano conseguirá um chefe do direito público que seja justo por si mesmo" (IaG, AA 08: 23). Não se trata de previsão por que essa possibilidade depende da escolha livre de tal sujeito, a qual, por isso, não pode ter nada como causa pré-determinante.

Esse terceiro aspecto relativo à boa vontade de um chefe justo por si mesmo não se restringe meramente ao âmbito exterior das ações, mas abrange também o aspecto motivacional. Isso fica patente quando Kant acrescenta na sequência, na sétima proposição do ensaio, que

Rousseau não estava enganado ao preferir o estado dos selvagens, se se deixar de lado o último estádio que a nossa espécie tem ainda de subir. Estamos cultivados em alto grau pela arte e pela ciência. Somos civilizados até ao excesso, em toda a classe de maneiras e respeitabilidade sociais. Mas falta ainda muito para nos considerarmos moralizados. Com efeito, a ideia de moralidade faz ainda parte da cultura; mas o uso desta ideia, que se restringe apenas aos costumes do amor matrimonial e na decência externa, constitui simplesmente a civilização. (Ia $G$, AA 08: 26)

Manuscrito - Rev. Int. Fil., Campinas, v. 37 , n. 1, p. 165 - 221, jan.jun. 2014. 
Ao se referir à civilidade, Kant aponta para as formas como os indivíduos se tratam e se relacionam, ou seja, ao âmbito externo da ação. Isso não constitui parte essencial daquilo que se chama moralidade e por isso, 'falta muito para nos considerarmos moralizados'. Sem esse último passo, avaliado teleologicamente, Rousseau não estaria enganado ao preferir o estado dos selvagens. A moralidade tem reflexos no agir externo, mas ela não se restringe a ele. Kant não poderia ser mais enfático e claro com relação a esse aspecto do que quando afirma: "todo o bem que não está imbuído de uma disposição de ânimo (Gesinnung) moralmente boa, nada mais é do que pura aparência e penúria coruscante." (IaG, AA 08: 26, negrito acrescentado) Não há dúvidas, portanto, de que na Ia $G$ Kant pensava que o progresso político-jurídico perpassava e dependia, a partir de certo momento, de um progresso moral que envolve o âmbito interno da ação, isto é, de um esclarecimento moral dos indivíduos, em especial daqueles que ocupam o cargo de legisladores. Nesse sentido, para a história universal da espécie humana,

o começo converte-se na fundação de um modo de pensar que, com o tempo, pode mudar a grosseira disposição natural em diferenciação moral relativa a princípios práticos determinados e, desse modo, metamorfosear também por fim uma consonância para formar uma sociedade, patologicamente provocada, num todo moral. (IaG, AA 08: 21)

Note-se, mais uma vez, que se trata de um "modo de pensar" (Denkungsart) e não simplesmente de um modo de agir, isto é, de uma forma comportamental que poderia ser alcançada por imposição, medo, costume ou premiações de qualquer espécie. É importante aqui ter em mente que no mesmo ano de 1784 Kant 
finaliza e publica a Fundamentação da metafísica dos costumes, onde distingue entre moralidade e legalidade (Cf. GMS, AA 04: 397ff). ${ }^{3}$

Em relação aos escritos histórico-políticos da década de noventa, há algumas modificações importantes. Uma delas é o deslocamento da centralidade do papel indivíduo legislador para o papel das instituições. A própria terminologia já indica essa mudança, sendo que em Ia $G$ se fala de um "chefe supremo" [höchste Oberbaupt], enquanto que em $\mathrm{ZeF}$, fala-se de instituições, as quais podem ser gradualmente aperfeiçoadas segundo o ideal republicano e do legislador como o "primeiro servidor do Estado" (Cf. ZeF, AA 08: 352. 33). ${ }^{4}$ Dito de outro modo, enquanto que na $I a G$ a tese do aperfeiçoamento depende essencialmente de uma concepção moral, em $Z e F$ o desenvolvimento é pensado primeiramente num âmbito político-institucional. ${ }^{5}$ Esse aspecto tem sido apresentado como o aspecto despersonalizante ou institucionalizante que surge na década

${ }^{3}$ No mesmo ano também pode ser encontrada a Vorlesungen über Naturrecht, transcrição das aulas de Kant sobre o direito natural, na qual Kant aponta para a diferença entre moralidade e direito, sendo o direito relacionado com a ação externa e legalidade e a moralidade com o fundamento de determinação da ação, isto é, com a disposição (Gesinnung) do agente. Nesse caso, Cf. Vorl. Naturrecht Feyerabend, AA 27.3: 1327.

${ }^{4}$ Outra passagem onde fica claramente indicado a centralidade que o aspecto institucional assume é a seguinte: “(...) exemplos de bons governos nada demonstram sobre a forma de governo. - Quem governou melhor que um Tito ou um Marco Aurélio? E, no entanto, um deixou como sucessor um Dominiciano, e o outro um Cómodo; o que não poderia ter acontecido com uma boa constituição política, pois a incapacidade dos últimos para o cargo tinha sido conhecida bastante cedo e o poder do Imperador era também suficientemente para os ter excluído.” (ZeF, AA 08: 353n.).

${ }^{5}$ Sobre uma caracterização e defesa mais detalhada dessa mudança ver PINZANI, 2009, 242-268, especialmente 259s. 
de noventa. Com essa nova perspectiva Kant passa a enfatizar mais a capacidade formativa da própria constituição republicana ao invés da boa vontade do soberano, ou seja, a própria constituição republicana, na forma como ela organiza a vida dos homens, tornaos bons cidadãos em suas ações, visto que ela se estrutura em torno dos princípios da liberdade dos membros de uma sociedade, da dependência de todos em relação a uma única legislação comum e da igualdade dos mesmos enquanto cidadãos (Cf. ZeF, AA 08: 349f. 0902). Além disso, separando o poder executivo e legislativo, o republicanismo evita o despotismo e, na visão de Kant, tende a evitar naturalmente a guerra. Em relação a esse aspecto institucionalizante não se apresenta divergências neste trabalho.

Contudo, os defensores de um progresso meramente jurídico da espécie humana defendem também que a figura do "legislador justo por si mesmo" e dotado de "boa vontade", central no ensaio da $I a G$, desapareceria por completo dos escritos políticos da década de noventa (Cf. Klein, 2013b). Nesse caso, na década de noventa o progresso jurídico se tornaria completamente independente do progresso moral, isto é, Kant abandonaria por completo o terceiro critério mencionado na sexta proposição, qual seja, a necessidade da boa vontade dos governantes. Essa posição da suficiência da racionalidade instrumental seria confirmada pela afirmação de que até mesmo uma sociedade de demônios, desde que tenham entendimento, conseguiriam fundar uma república, já que para tal empresa bastaria um mero cálculo instrumental. Em outras palavras, a criação de uma República dependeria exclusivamente do uso da faculdade do entendimento para coadunar e contrabalançar os efeitos de intenções egoístas de modo que eles se autodestruíssem.

$\mathrm{Na}$ próxima seção defende-se que mesmo com a institucionalização do Estado em torno de princípios republicanos, onde o soberano não legisla arbitrariamente, mas se apresenta

Manuscrito - Rev. Int. Fil., Campinas, v. 37 , n. 1, p. 165 - 221, jan.-jun. 2014. 
como o "primeiro servidor do Estado", não se pode evitar o fato de que o governante, seja na figura de uma pessoa ou de um grupo, sempre será também um ser que tende a se subtrair da lei ou a estabelecê-la segundo seus próprios interesses egoístas, o que, portanto, tende a corromper o funcionamento do Estado. Nesse caso procura-se mostrar que a tese de um progresso meramente jurídico defendida a partir do argumento sustentado sobre a interpretação da passagem relativa a sociedade de demônios não se sustenta, seja a partir de uma interpretação acurada daquela passagem, seja a partir de dos problemas e contradições textuais e argumentativas que ela provoca.

\section{SOBRE A SUPOSTA "REPÚBLICA" DE DEMÔNIOS DOTADOS DE ENTENDIMENTO}

Divide-se a argumentação desta seção em dois momentos: primeiro, faz-se uma análise do que seria o conceito kantiano de uma "república de demônios" racionais e do que ela pressupõe; ${ }^{6}$ e, num segundo momento, discute-se detalhadamente a passagem e o contexto onde esse conceito é supostamente apresentado e

${ }^{6}$ Como informação relevante, cabe dizer que a formulação de um estado de demônios parece ser uma resposta à Recensão de Rehberg ao texto de Kant TP. Nessa recensão Rehberg escreve: "A totalidade do sistema de uma sociedade civil que se sustenta sob princípios a priori é uma ideia que só pode ser aplicada num mundo onde seus membros fossem seres perfeitamente livres (metafisicamente) e fossem os criadores do seu próprio campo de atuação. Rousseau (cuja teoria do senhor Kant no essencial concorda tão perfeitamente que só se precisa intercalar a terminologia do Contrato Social nos lugares adequados) nota ele próprio que o seu sistema só poderia servir para uma república de deuses.” (Rehberg, 1967, 127, tradução própria)

Manuscrito - Rev. Int. Fil., Campinas, v. 37 , n. 1, p. 165 - 221, jan.jun. 2014. 
defendido, algo que é tomado como certo pela maior parte da literatura.

Segundo Kant, um Estado pode ser considerado uma República se ele respeitar os seguintes critérios:

1. Numa República, os súditos são ao mesmo tempo os soberanos, isto é, as leis devem poder ser compreendidas como dimanando da vontade unida do povo, ou ainda, os súditos devem poder concordar com todas as leis estabelecidas, pois o que se busca não é a felicidade, mas a liberdade (Cf. TP, AA 08: 297; MS, AA 06: 318);

2. Nesse sentido a constituição republicana é organizada segundo três princípios: da liberdade dos membros de uma sociedade, da dependência de todos em relação a uma única legislação comum e, em terceiro lugar, a igualdade dos mesmos perante a lei (Cf. ZeF, AA 08: 350n.; TP, AA 08: 290ff.; MS, AA 06: 314);

3. Um estado somente pode ser considerado republicano quando o governo é exercido de forma representativa e com a divisão dos poderes em legislativo, executivo e judiciário (Cf. ZeF, AA 08: 291; MS, AA 06: 313, 318, 341);

4. A constituição republicana é aquela que tende a evitar naturalmente a guerra, seja a partir de uma "perspectiva utilitarista" (pois "se exige o consentimento dos cidadãos para decidir se deve ou não haver guerra, então nada é mais natural do que deliberar muito em começarem um jogo tão maligno, pois têm de decidir para si próprios todos os sofrimentos da guerra" (Cf. ZeF, AA 08: 351)), seja por que ela simplesmente ordena que não deve haver guerra na medida em que tanto os indivíduos e cidadãos, quanto os próprios Estados vizinhos são pessoas morais que não podem ser tratados simplesmente como meios ("esta é a única Constituição política estável, em que a lei ordena por si própria e não está na dependência de nenhuma pessoa em particular” (MS, AA 06: 341);

Manuscrito - Rev. Int. Fil., Campinas, v. 37 , n. 1, p. 165 - 221, jan.-jun. 2014. 
“Ora, a razão prático-moral pronuncia em nós o seu veto irrevogável: não deve haver guerra; nem aquela que pode ocorrer entrem mim e ti no estado de natureza, nem aquela que pode ocorrer entre nós enquanto Estados, que, encontram-se, porém, externamente (na sua relação recíproca) num estado sem lei; - pois que este não é o modo em conformidade com o qual cada um deve procurar seu direito" (MS, AA 06: 354)). Dito ainda de outra forma, a constituição da respublica phaenomenon "qualifica-se como a melhor entre todas para manter afastada a guerra, destruidora de todo o bem" (SF, AA 07: 91);

5. A ideia de uma constituição republicana não é uma utopia vazia, mas é um ideal normativo da razão, isto é, trata-se da "ideia de uma constituição em consonância com o direito natural dos homens". A respublica noumenon se impõe como uma norma eterna para toda a constituição civil. Ainda que tal constituição jamais possa existir em sua perfeição no mundo fenomênico, permanece a necessidade e a possibilidade de se aproximar gradualmente ad infinitum daquele ideal (Cf. SF, AA 07: 91).

Em suma, para que uma constituição republicana possa ser qualificada como tal, ela deve poder satisfazer os cinco critérios apresentados acima. Não basta que ela seja constituída segundo a separação de poderes, mas ela precisa se fundar sobre os princípios da liberdade, igualdade e dependência. Isso, por sua vez, já a vincula também com a característica intrínseca de sempre orientar a sua política no sentido de tomar medidas que a aproximem gradativamente do ideal da república noumenon. Uma república que satisfizesse todos menos o quinto critério, ainda não poderia ser considerada uma república em sentido estrito, pois lhe falta a tendência de aperfeiçoar suas próprias instituições.

$\mathrm{O}$ que seriam os demônios? Em primeiro lugar, demônios como conceito antagônico de anjos, não pode indicar um ser que seja equivalente ao ser humano, isto é, ainda que não sejam seres

Manuscrito - Rev. Int. Fil., Campinas, v. 37 , n. 1, p. 165 - 221, jan.jun. 2014. 
absolutamente malévolos, precisam ser qualificados como seres que não possuem a capacidade de agir por dever, mas que agem sempre apenas segundo inclinações egoístas. Em suma, seriam seres que possuiriam apenas entendimento e não uma razão prática pura (Cf. $R G V$, AA 06: 35; $M S$, AA 06: 461). ${ }^{7}$

Ao se afirmar a possibilidade de uma república de demônios, defende-se que os demônios, na medida em que estejam conscientes e esclarecidos a respeito de seu verdadeiro interesse, o qual, por sua vez, pode ser alcançado por meio de um mero cálculo pragmático, optariam conjuntamente por estabelecer uma constituição republicana segundo os três primeiros critérios acima expostos, sendo que o quarto e o quinto critério seriam dotados de uma normatividade condicionada, pois estariam fundados sobre um imperativo pragmático. Nesse caso, a justificação do Estado seria baseada nos interesses próprios e egoístas, ainda que bem compreendidos, de cada um em preservar o máximo de liberdade individual.

Contudo, para se chegar a uma conclusão sobre a possibilidade de os demônios optarem por uma constituição republicana, visto que ela seria fruto de uma mera reflexão teóricopragmática, é preciso realizar a seguinte pressuposição fundamental: que todos teriam a capacidade de se prejudicar mutuamente e de forma semelhante, de tal modo que as vantagens que pudessem resultar de uma postura que transgrida as normas de uma constituição republicana não ultrapassassem muito as

${ }^{7}$ Concorda-se com a caracterização do conceito de povo de demônios feita por Niesen (2001, pp.584ss), contudo, a partir dos argumentos que se seguem, discorda-se dele na medida em que ele apresenta uma caracterização do republicanismo kantiano como algo completamente independente do aspecto moral, ou seja, que Kant colocaria no centro da sua teoria republicana o interesse egoísta bem entendido e retira o discurso sobre a virtude (pp.582s).

Manuscrito - Rev. Int. Fil., Campinas, v. 37 , n. 1, p. 165 - 221, jan.jun. 2014. 
desvantagens sofridas de tal postura. Essa pressuposição se assenta, por sua vez, em outra, a saber: de que todos tenham também a plena consciência na maioria das circunstâncias e momentos, de que o seu verdadeiro interesse não é equivalente ao seu interesse individual num determinado momento e de que todos estão de fato em condições iguais de se prejudicar de forma equânime. Em outras palavras, a possibilidade de uma república de demônios se apresenta como um ideal da imaginação, pois a experiência mostra que seres que agem por pura inclinação egoísta tendem a se comportar muito mais como uma "sociedade de ladrões", isto é, como um grupo que se une segundo rígidos princípios "morais" para poder exercer livremente suas tendências egoístas sobre outros indivíduos que não fazem parte do grupo. Nesse caso, pode-se dizer que, em sentido muito abstrato, é possível representar uma república de demônios, mas apenas no sentido de que não existe uma contradição interna ao conceito, contudo, da falta de uma contradição formal não se segue a sua possibilidade real ou a conformidade à experiência, ou seja, pode não haver uma contradição formal, mas haveria uma implausibilidade material, que beira a contradição material. ${ }^{8}$ Portanto, defende-se que no mundo real, tal como o conhecemos,

${ }^{8}$ Segundo Brandt $(1997,233 s)$, para Kant não importa como de fato os demônios podem organizar Repúblicas, mas simplesmente que isso seria possível. Mais à frente (236) ele acaba reconhecendo que os Demônios não agiriam como bons cidadãos e nem como bons bourgeois segundo o conceito de direito tal como apresentado na MS. Mas essas considerações não modificam a sua posição de que para Kant demônios podem organizar e viver em repúblicas. Contudo, discordo de Brandt, pois acredito que investigar mais a fundo essa possibilidade e suas pressuposições permite compreender melhor qual a relação dessa analogia com a possibilidade dos homens formarem repúblicas. A compreensão dessa implausibilidade, por exemplo, conduz a uma consideração mais atenta do próprio texto e das suas formulações exatas.

Manuscrito - Rev. Int. Fil., Campinas, v. 37 , n. 1, p. 165 - 221, jan.jun. 2014. 
seria possível que demônios formassem sociedades e até Estados, mas não Repúblicas. Muito menos seriam elas por sua própria natureza pacíficas, pois demônios seriam sempre demônios na relação com outros Estados. Nesse sentido, o próprio Höffe (2001, p. 216s) acaba reconhecendo essas dificuldades ao investigar se as democracias (que corresponderiam ao conceito de república kantiana) seriam mais pacíficas do que estados não democráticos.

Passa-se agora à análise da suposta passagem na qual Kant teria feito essa afirmação:

1. Em primeiro lugar, essa passagem se encontra no Suplemento primeiro, Da garantia da paz perpétua. Isso significa que, apesar de se tratar de um texto vinculado à parte inicial - a qual trata de artigos preliminares e definitivos para a paz perpétua e, por conseguinte, se mantém eminentemente no campo da filosofia prática stricto sensu - ele se insere num outro referencial teórico, o da teleologia da natureza. Nesse caso, o fato de Kant inserir uma consideração de teor extrajurídico, isto é, moral, não compromete o caráter meramente jurídico da primeira e segunda seção do ensaio. Dito de outra forma, a inserção de consideração éticomorais no nível de discussão teleológica não corrompe a natureza estritamente jurídica da legitimação do conceito de uma constituição republicana que acontece na primeira parte da $\mathrm{ZeF}$.

2. Kant fala que o conceito de Natureza não serve para reconbecer teoricamente o que irá acontecer, mas apenas nos possibilita pensar que ela serve como garantia para o progresso da humanidade em direção à paz perpétua. Não se trata de um mero pensamento vazio, mas sim de uma representação que se encontra bem fundada no âmbito prático. E agora é importante citar a seguinte passagem que encerra uma importante nota sobre $\mathrm{O}$ conceito de providência que será adotado:

Manuscrito - Rev. Int. Fil., Campinas, v. 37 , n. 1, p. 165 - 221, jan.-jun. 2014. 
Mas num sentido prático-moral (que se refere totalmente ao suprassensível), o conceito do concursos divino é conveniente e até necessário; por exemplo, na fé de que Deus completará a deficiência da nossa própria justiça, se a nossa disposição for genuína, através de meios para nós inconcebíveis, portanto, se nada descurarmos no esforço pelo bem, mas é evidente que ninguém deve intentar explicar a partir daqui uma ação boa (como acontecimento no mundo) - que é um pretenso conhecimento teórico do suprassensível, por conseguinte, um absurdo. (ZeF, AA 08: $362 n)$

Ora, obviamente Kant não se está pensando num esquema meramente jurídico, pois ele fala de disposição de ânimo, ainda que não se possa conbecê-la. Além disso, não se fala aqui de uma justiça que será realizada num além mundo, pois trata-se de um concurso no mundo, ou seja, obviamente não se tem em vista aqui a filosofia da religião, mas a filosofia da história.

3. A formulação exata de Kant é: “o problema do estabelecimento de um Estado, por mais áspero que soe, tem solução, inclusive para um povo de demônios (contanto que tenham entendimento)" (ZeF, AA 08: 366). Não existe uma formulação inequívoca de que Kant estaria afirmando que demônios com entendimento poderiam instituir uma constituição republicana, mas sim apenas um Estado, o qual deve poder solucionar o seguinte problema:

Ordenar uma multidão de seres racionais que, para a sua conservação, exigem conjuntamente leis universais, às quais, porém, cada um é inclinado no seu interior a eximir-se, e estabelecer a sua constituição de um modo tal que estes, embora opondo-se uns aos outros nas suas disposições privadas, se contêm no entanto reciprocamente, de modo que o resultado da sua 
conduta pública é o mesmo que se não tivessem essas disposições más. (ZeF, AA 08: 366.) ${ }^{9}$

Ora, esse excerto não é necessariamente uma definição de constituição republicana, pois se fala de "leis universais", no sentido de serem válidas para todos, mas não de leis universais baseadas no princípio universal da liberdade. Nesse caso, o que está em questão aqui é que uma boa organização do Estado. Contudo, uma "boa organização" do Estado não é ainda a melhor e nem a mais justa. Além disso, como foi mostrado anteriormente, ainda que seja possível pensar abstratamente numa república de demônios, existe uma implausibilidade material de que eles por si próprios estabelecessem e mantivessem tal regime. No caso dos seres humanos, a situação seria ainda mais implausível, pois são bastante distintos entre si a respeito de suas capacidades, por conseguinte, aquela implausibilidade se transforma mesmo em uma impossibilidade.

Mas então, qual seria a intenção de Kant ao utilizar a analogia com o povo de demônios? O que Kant está afirmando exatamente na passagem é que não se precisa de bons indivíduos para que se funde um Estado no qual as disposições não pacíficas sejam coordenadas de forma a se destruírem em seus efeitos. Por conseguinte, também não se precisa de Repúblicas para se fundar uma federação de nações. Todavia, para que a constituição dos Estados evolua para uma Constituição republicana em sentido estrito e para que também a Federação das nações evolua e se solidifique numa verdadeira Federação da paz, para isso é preciso mais do que uma mera razão instrumental esclarecida. Em outras palavras, a Natureza pode conseguir através da sociabilidade

\footnotetext{
${ }^{9}$ O próprio Brandt $(1997,235)$ reconhece que Kant parece estar retrocedendo em seu argumento. Contudo, ele afirma que isso seria apenas uma aparência.
}

Manuscrito - Rev. Int. Fil., Campinas, v. 37 , n. 1, p. 165 - 221, jan.-jun. 2014. 
insociável que os indivíduos se reúnam em Estados, e também pode forçar os Estados a estabelecerem uma regulação jurídica entre si. Mas um estado justo não é apenas um estado bem organizado e a paz perpétua não será alcançada apenas com Estados reunidos numa federação, mas somente quando houver uma federação de Estados republicanos. A natureza promove a paz através do antagonismo, mas a paz perpétua precisa ser promovida pelo próprio homem, através de ações políticas livres que não se limitem a mera legalidade do direito.

Portanto, Kant não afirma que demônios com entendimento possam alcançar uma constituição republicana de natureza pacífica, a qual "é a mais difícil de estabelecer, e mais ainda de conservar" (ZeF, AA 08: 366). Seria, no mínimo, estranho representar um povo de demônios que: estabeleceriam tratados de paz sem a reserva secreta de rompê-los; não tentassem adquirir outros Estados por conquistas ou barganhas, não os tratando como objeto, mas como uma pessoa moral; abdicassem de possuir exércitos permanentes frente a outros povos de demônios; não tentassem imiscuir-se pela força na constituição e no governo de outro Estado; e, por fim, durante o estado de guerra, não empregassem os serviços de assassinos, envenenadores e traidores noutros Estados (Cf. os artigos preliminares de ZeF). Tudo isso a partir de um simples cálculo pragmático e utilitário.

Mas então, o que se ganha com a conclusão de que um povo de demônios poderia viver conjuntamente em um Estado segundo leis universais? Ora, se os demônios podem fazer isso, os seres humanos (em especial o governante e os legisladores), como seres moralmente obrigados, podem e devem não apenas construir um tal Estado bem articulado, mas também podem e devem fundar Repúblicas (no sentido pleno do termo).

Haveria assim três estágios: o estado de natureza, o estabelecimento de um Estado e o estabelecimento de um Estado 
com uma Constituição republicana. Isso também no âmbito internacional: o estado de natureza entre os Estados, uma Federação das nações (como sucedâneo negativo de uma federação antagônica à guerra) e uma Federação das repúblicas ou Federação da paz (na ideia de uma República mundial) (Cf. ZeF, AA 08: 357). $O$ estabelecimento do Estado não precisa se assentar sobre a constituição moral dos homens, mas lhe basta o antagonismo das suas inclinações egoístas. Agora, uma vez que um Estado possua uma boa constituição (com alguns traços da constituição republicana), então se pode esperar dela um espaço para uma boa formação moral do povo. Desse modo, a partir de um gradual esclarecimento moral do povo e, por conseguinte, dos governantes, pode-se esperar que aquele Estado se reforme continuamente ate que possa ser considerado como uma República, a qual procuraria cada vez mais se aproximar do ideal de respulbica noumenon que a razão prática pura prescreve. Também uma Federação das nações não precisa que os Estados sejam verdadeiras repúblicas para ser constituída, pois ela pode surgir como o amargo remédio de uma situação sem leis, o que, todavia, ainda não passa de um estado de contínua guerra. Mas para que surja uma Federação da paz é preciso que o centro de construção seja uma República, ${ }^{10}$ na qual outros Estados se unam e a partir do que se espera que gradativamente se tornem também Repúblicas. Em suma, a transição do segundo para o terceiro estágio pressupõe uma relação dialógica (que ultrapassa a mera consideração utilitária e pragmática

${ }^{10} \mathrm{O}$ texto de Kant não diz que o centro precisa ser uma República, ele apenas sugere fortemente que isso assim o seja. Acredito que Kant ainda estava cauteloso em 1795 sobre esse aspecto, pois havia ainda certa insegurança a respeito dos eventos da Revolução francesa e de suas implicações na Prússia. Contudo, em 1798, Kant parece ser mais incisivo, afirmando que a constituição republicana é a melhor constituição possível para manter afastada a guerra.

Manuscrito - Rev. Int. Fil., Campinas, v. 37 , n. 1, p. 165 - 221, jan.jun. 2014. 
que poderia ser garantida pela Natureza ou pensada num nível da mera racionalidade instrumental) entre o Estado e o indivíduo. É nessa situação limite que entra em cena o campo de atuação da liberdade humana no seu sentido mais pleno. ${ }^{11}$

Ora, o resultado dessa leitura reconhece que Kant minimiza os efeitos da boa vontade do soberano para a consecução de uma boa constituição, uma vez que ressalta o papel formativo da própria constituição do Estado sobre a formação do povo. Entretanto, diferentemente da leitura de Brandt (1997), Höffe (2001, p.208), Niesen (2001) e Pinzani (2009), ${ }^{12}$ defende-se que não houve o abandono da necessidade de uma boa vontade do governante e dos cidadãos em geral para a realização da ideia do direito e para a fundação de uma verdadeira República (que satisfaça os cinco critérios anteriormente expostos).

${ }^{11}$ Segundo Brandt, o cerne do argumento de Kant na passagem seria: "que o estado de perfeita administração da justiça, ao qual os demônios necessariamente querem e também podem conceber é em sua grande totalidade isomorfo com a República, a qual a razão prática pura ordena aos homens não por princípios de utilidade, mas por princípios morais. Apenas por que a 'utilidade' conduz finalmente para a mesma direção que a 'justiça' (...)" (Brandt, 1997, p. 236. tradução própria). Contudo, pela minha interpretação chego ao mesmo resultado que Brandt, isto é, afirmando que a utilidade segue a mesma direção que a moralidade, sem todavia dizer que a utilidade chega por si só ao mesmo ponto final.

${ }^{12}$ De certa forma também Pinzani parece reconhecer que no decorrer da história as instituições podem melhorar "graças à vontade reformatória do bem intencionado monarca, à atividade esclarecida dos eruditos, e não por último, ao modo de pensar republicano dos cidadãos" (Pinzani, 2009, p. 263 , tradução própria). Ou seja, ele parece reconhecer que o desenvolvimento das instituições acaba pressupondo novamente uma boa vontade e uma virtude. Pinzani tende a interpretar essa virtude dentro dos limites do direito (como moralidade jurídica ou virtude cívica). 
Além disso, após a seção sobre $A$ garantia da paz perpétua, a vinculação do progresso jurídico a um progresso moral pode ser sustentada também a partir de outros três momentos decisivos do texto. O primeiro elemento textual se apresenta na defesa da necessidade de um político moral, isto é, naquele político que age segundo o seguinte princípio:

Se alguma vez na constituição de um Estado ou nas relações entre Estados se encontrarem defeitos que não foi possível impedir, é um dever, sobretudo para os chefes de Estado, refletir o modo como eles poderiam, logo que possível, corrigir e coadunar-se com o direito natural, tal como ele se oferece aos nossos olhos como modelo na ideia da razão, mesmo que tenha de custar o sacrifício do amor próprio. (ZeF, AA 08: 372$)^{13}$

${ }^{13}$ A relação dessa passagem com a interpretação da tese da república de demônios deu ensejo ao duro debate entre Ludwig (1997, pp. 225ss; 1998) e Brandt (1997). Segundo Ludwig, uma república de demônios somente seria possível se houvesse um legislador moral que impusesse a constituição e a mantivesse. Brandt, por seu turno, respondeu que, apesar de haver dificuldades com o conceito de uma república de demônios, ela é pensável independentemente de um político moral. Ludwig (1998) rebate essa crítica argumentando que em nenhum momento da argumentação Kant legitima que uma Natureza deísta hipostasiada seja a agente da história, isso significa que sempre se trata da liberdade do homem de colocar os seus próprios fins (e os demônios não conseguiriam por si próprios erigir uma república, pelos motivos que já foram apresentados acima). Nesse caso, o verdadeiro intento do argumento de Kant na república dos demônios é contra-argumentar com os governantes, cuja escusa é a de que uma República só serviria para um povo de anjos. Ou seja, Kant estaria mostrando que um governo republicano seria possível inclusive para um povo de demônios, desde que os governantes cumprissem com o seu dever e estabelecessem uma constituição republicana. Nesse aspecto concorda-se com Ludwig, pois esse mesmo problema é retomado em $S F$, na disputa com os juristas que querem 
O governo de um país não se constitui somente em aplicar as leis existentes, mas também em reformá-las ou criar novas. Nesse caso, uma república justa segundo o ideal de uma respublica noumenon é governada por tudo menos do que por políticos moralizantes, os quais "mediante a desculpa de princípios políticos contrários ao direito sob o pretexto de uma natureza humana incapaz do bem, (...) tornam impossível, tanto quanto deles depende, o melhoramento e perpetuam a violação do direito.” ( $\mathrm{ZeF}$, AA 08: 373) Nesse sentido, Kant indica claramente que o único governo republicano autêntico só pode ser pensado por um político moral (Cf. ZeF, AA 08: 377. 30-31). Em suma, quando a lei positiva ainda não existe e deve ser criada ou quando ela já existe, mas precisa ser reformada, ou seja, quando não se trata apenas de administração de um determinado direito positivo, então, nesses casos a ideia do direito deve se tomar o próprio fim e móbil e, portanto, não se trata mais apenas de uma liberdade ou motivação jurídica, mas também de uma motivação moral que se enraíza na disposição de ânimo do legislador (Cf. Guyer, 2009, pp. 134-143). Note-se que aqui não se está afirmando que toda criação ou aplicação correta da lei justa somente ocorre quando o legislador ou o chefe do executivo estão imbuídos de uma boa disposição de ânimo, pois é sempre possível que isso decorra de um feliz acaso em que a busca pela utilidade e satisfação de interesses egoístas se coaduna com a moralidade. O que se está apontando aqui é que, na visão de Kant, para que leis justas sejam criadas e aplicadas corretamente de modo não apenas eventual, mas constante e sistemático, para isso uma boa disposição moral é imprescindível.

O segundo momento que mostra a vinculação entre direito e ética em relação ao progresso do Estado é a formulação do

legislar com base no que eles afirmam ser a suposta natureza do ser humano.

Manuscrito - Rev. Int. Fil., Campinas, v. 37 , n. 1, p. 165 - 221, jan.jun. 2014. 
princípio da publicidade como critério moral das ações dos governantes, qual seja, que "são injustas todas as ações que se referem ao direito de outros homens, cujas máximas não se harmonizem com a publicidade" (ZeF, AA 08: 381). Se o objetivo da ação é frustrado quando se torna pública a máxima, então a máxima é injusta, é imoral, mas se apenas com a publicidade o resultado é alcançado, então a máxima é justa, é moral. Castillo (2004) interpreta esse princípio de publicidade como se referindo à defesa de Kant por uma esfera pública livre na qual vigorasse a liberdade de imprensa e a liberdade de atuação do filósofo para apresentar ao público as verdadeiras máximas pelas quais os políticos agem. Sem dúvida esse é um aspecto imprescindível para a legitimidade da representação política, pois sem a possibilidade de um uso público da razão, condena-se a humanidade à perpétua menoridade (Cf. WDO, AA 08: 144. Anth. AA 07: 219) e fere-se diretamente o direito de liberdade de um uso público da razão (Cf. TP, AA 08: 304). Todavia, querer restringir o princípio da publicidade a esse aspecto, o qual poderia ser realizado simplesmente a partir da perspectiva jurídica, depende, mais uma vez, de se fazer violência ao texto kantiano. Veja-se que a formulação é inequívoca: trata-se da máxima, isto é, do princípio subjetivo do agir, o qual faz uma referência inequívoca à disposição de ânimo do indivíduo. ${ }^{14}$ Assim, a

${ }^{14}$ Niesen (2001, p. 594) parece sugerir que uma sociedade de demônios cumpriria esse critério da publicidade das máximas. Contudo, não acredito que esse seja o caso, a menos que se pressuponha uma moralidade oculta nesses seres egoístas ou que eles tenham extraordinárias faculdades cognoscitivas que lhes permitissem vigiar constantemente o comportamento de todos os contratantes. Dito de outra forma, ou se pressupõe que, apesar dos seus interesses egoístas individuais, há um respeito pela constituição republicana de modo a não infringir a lei no momento em que se age, ou os indivíduos egoístas devem ter uma crença bem assentada de que se eles quebrarem o pacto, então eles tem grandes

Manuscrito - Rev. Int. Fil., Campinas, v. 37 , n. 1, p. 165 - 221, jan.jun. 2014. 
leitura restritiva de Castillo parece fracassar, pois mesmo que um governo adotasse diversas medidas de transparência política, na qual divulgasse informações, tanto relativas ao funcionamento do governo, quanto as suas intenções políticas, isso não garantiria novamente que as informações apresentadas e que as propostas feitas sejam verdadeiras. É isso que Kant deixa subentendido quando ele afirma que "é, sem dúvida, de admirar que a palavra direito não tenha ainda podido ser expulsa da política da guerra com pedante, e que nenhum Estado tenha ainda ousado manifestarse publicamente a favor desta última opinião; pois continuam a citar-se candidamente Hugo Grócio, Pufendorf, Vatel e outros (incômodos consoladores apenas!)” (ZeF, AA 08: 355). Essa relutância em não abandonar a palavra direito indica, segundo Kant, uma disposição moral mais profunda, que permite esperar que a humanidade se aproxime constantemente da paz perpétua, mas também indica que é sempre possível que os legisladores e chefes de Estado continuem apresentando um discurso na esfera pública, mas ajam segundo máximas contrárias. Por isso, em última instância, para que a paz possa ser construída politicamente de modo gradual e firme os legisladores e o chefe de Estado precisam assumir como sua máxima o princípio da publicidade nas suas ações políticas.

chances de serem descobertos e punidos. Mas isso pressupõe novamente que as instituições que os vigiam sejam por sua vez morais e não podem ser corrompidas por suborno, ou que o "vigiar" seja exercido por grande parte dos cidadãos (de forma que o suborno não possa ser exercido), o que é implausível a menos que se atribua uma capacidade cognoscitiva superior a esses indivíduos. Portanto, apenas máximas boas são passíveis de serem universalizadas e apenas indivíduos que adotam de fato e não apenas ficticiamente máximas boas, se dispõe a permanecer fiel ao seu cumprimento.

Manuscrito - Rev. Int. Fil., Campinas, v. 37 , n. 1, p. 165 - 221, jan.-jun. 2014. 
O terceiro elemento textual que corrobora a vinculação entre direito e ética na condução da política é indicado pela problemática do mal. Poderia-se surpreender que Kant tenha empregado a mesma metáfora do lenho retorcido da $I a G$ também na $R G V$, especificamente no contexto da discussão do triunfo do princípio bom sobre o princípio mau (Cf. $R G V$, AA 06: 100). Ou mesmo com a retomada desse tema na própria $Z e F$ :

(...) esta homenagem que todos os Estados prestam ao conceito de direito (pelo menos, de palavra) mostra, no entanto, que se pode encontrar no homem uma disposição moral ainda mais profunda, se bem que dormente na altura, para se assenhorear do princípio mau que nele reside (o que não pode negar) e para esperar isso também dos outros; pois, de outro modo, a palavra direito nunca viria a boca desses Estados que se querem guerrear entre si (...). (ZeF, AA 08: 355)

Esse parece ser um excerto típico de textos de ética. Os conceitos não enganam, trata-se do tema do princípio mau que pode ser vencido pelo princípio bom, o qual não é meramente jurídico legal, pois se refere à disposição moral dos indivíduos que sustenta a própria ideia de direito.

Ora, a partir do que foi mostrado nessa seção pode-se reler o texto a partir de uma nova visão sobre a relação entre a razão prática e a racionalidade pragmática. O que Kant quer mostrar é que a perspectiva moral não contradiz necessariamente a perspectiva pragmática, isto é, existem elementos da racionalidade pragmática que estão em pleno acordo com aquilo que prescreve a razão prática. Nesse sentido é que devem ser lidas as considerações sobre o povo de demônios, a diversidade das línguas e religiões e o interesse pacífico do comércio. Isso significa então que:

a moral tem em si a peculiaridade e, claro está, no tocante aos seus princípios do direito público (por conseguinte, em relação a uma política cognoscível a priori) de que quanto menos faz depender o

Manuscrito - Rev. Int. Fil., Campinas, v. 37 , n. 1, p. 165 - 221, jan.-jun. 2014. 
comportamento acerca do fim proposto, da vantagem intentada, seja ela física ou moral, tanto mais com ele se torna em geral dada a priori (num povo ou na relação de vários povos entre si) a única que determina o que é de direito entre os homens; esta união da vontade de todos, porém, se proceder consequentemente na execução, também segundo o mecanismo da natureza pode ser ao mesmo tempo a causa capaz de produzir o efeito intentado e de pôr em prática o conceito de direito. (ZeF, AA 08: 378)

Em outras palavras, a moral e a sabedoria política não contradizem o mecanismo da natureza, ou ainda, o fim da moral pode ser alcançado, pois não contradiz necessariamente os interesses egoístas dos indivíduos, desde que eles sejam bem compreendidos. Porém, o que Kant não está defendendo é que a racionalidade pragmática poderia chegar por si só ao mesmo fim que a razão prática prescreve, pois isso tornaria a própria razão prática pura algo supérfluo no processo, sendo que uma verdadeira República poderia ser alcançada inclusive por um povo de demônios ou por meios meramente técnico-prudenciais. A posição kantiana também pode ser expressa da seguinte forma: os fins da racionalidade pragmática podem ser subsumidos aos fins da racionalidade prática, mas os fins $\mathrm{da}$ racionalidade prática extrapolam os fins da racionalidade pragmática. Mais do que isso: Kant defende que apenas buscando os fins da racionalidade prática é que os fins da racionalidade pragmática também podem ser alcançados, porém buscando-se apenas os fins da racionalidade pragmática, então nada é alcançado e os homens se tornariam as criaturas mais miseráveis de todos os seres do universo (Cf. ZeF, AA 08: 378).

Ora, a leitura teleológica dos textos históricos-políticos de Kant traz à tona nuances que tendem a diluir, sob certas perspectivas, a fronteiras entre o direito e a ética, uma vez que o a ideia do direito racional deve ser assumida na disposição de ânimo dos indivíduos, especialmente nos políticos. Dito de outra forma, na ação política os indivíduos devem estar dotados de uma boa Manuscrito - Rev. Int. Fil., Campinas, v. 37 , n. 1, p. 165 - 221, jan.-jun. 2014. 
vontade. Essa diluição da fronteira entre direito e ética se torna necessária no campo do pensamento histórico e político, pois mantê-los sempre como âmbitos isolados pode ter como custo a própria inteligibilidade da ação prática tal como apresentada pela filosofia kantiana. Portanto, Kant não abandona na década de noventa a tese da importância da disposição moral do governante (do rei, dos políticos ou dos representantes do povo responsáveis pela criação, reformulação e aplicação das leis) para que uma constituição se torne gradualmente mais justa, a qual, por sua vez, promoverá a boa formação moral do povo.

Se a reconstrução acima estiver correta, então se coloca inevitavelmente a questão de como o ser humano pode tornar-se um ser moral. Dito de outra forma, como o ser humano pode lidar com suas inclinações egoístas para que elas não o transformem num ser egoísta, ou, caso isso já tenha ocorrido ou esteja em processo, como essa situação pode ser contornada? Isso conduz naturalmente ao tema de como pode ser possível o aperfeiçoamento moral dos indivíduos e como isso se relaciona com o Estado.

\section{ESCLARECIMENTO MORAL: O PAPEL DO ESTADO EM UM EDUCAÇÃO MORAL}

Pensar a questão do esclarecimento moral conduz a uma análise das forças e dos meios promotores do progresso políticomoral que estão ao alcance do indivíduo e de um determinado povo. Ou ainda, como e quanto, na filosofia da história, o progresso político-moral da humanidade está vinculado à necessidade da atuação intencional do ser humano na construção da República esclarecida e, por conseguinte, quanto do progresso depende de um plano racional posto em prática pelo próprio Estado? Nas palavras de Kant, 
também pode-se progredir na cultura de forma cega e sem plano, e a Natureza também não nos deixou escolha a esse respeito. Mas ao nos aproximamos com isso do fim, então é preciso que um plano seja realizado: estabelecendo-se um ponto de ligação na Educação, no Governo e na Religião entre felicidade e moral. (Refl. 1523, AA 15: 896. Tradução própria e negrito acrescentado)

O horizonte no qual esse tema pode ser argumentativamente inserido é no embate entre Kant e Herder. $\mathrm{O}$ antigo discípulo critica a tese kantiana de que "no homem as disposições naturais que visam o uso da razão devem desenvolver-se só na espécie, e não no indivíduo" (IaG, AA 08: 18). Segundo Herder,

Existe portanto uma educação do gênero humano, pois cada homem se torna um homem apenas por meio da educação e todo o gênero não vive senão nessa série de indivíduos. No entanto, se alguém diz que não é o homem singular, mas o gênero que é educado, então fala para mim algo incompreensível, pois gênero e espécie são apenas conceitos gerais que existem nos seres singulares. Ora, se eu desse a esse conceito universal toda a perfeição da humanidade, cultura e o mais alto esclarecimento que se permite a um conceito ideal, então eu teria dito tanto sobre a verdadeira história do nosso gênero, quanto se eu tivesse falado de forma geral e com esplendor sobre a animalidade, a mineralidade ou metalidade e as colocado em contradição com os atributos dos indivíduos singulares. Esse caminho da filosofia averroísta (...) não será trilhado por nossa filosofia da história. (Herder, 1985, p. 226. Tradução própria)

Kant não apenas refuta veementemente a validade dessa crítica, como também se irrita profundamente com ela, pois segundo ele,

quem diz que nenhum cavalo individual possui chifres, mas que a espécie equina o possui, esse diria simplesmente uma absurdidade. Pois espécie não significa nada além do que uma característica segundo a qual todos os indivíduos precisam concordar exatamente uns com os outros. Mas se a espécie humana significa um todo de

Manuscrito - Rev. Int. Fil., Campinas, v. 37 , n. 1, p. 165 - 221, jan.jun. 2014. 
uma série contínua e infinita (indeterminável) de gerações (tal como é o sentido mais comum), e assumindo-se que essa série se aproxima incessantemente da linha de sua determinação, a qual corre ao seu lado, então se pode dizer que não há nenhuma contradição. (RezHerder, AA 08: 65. Tradução própria)

Em outras palavras, apenas haveria uma contradição se se afirmasse que a espécie pode progredir, mas não o indivíduo, o que seria o mesmo que dizer que nenhum cavalo individual possui chifres, mas a espécie equina o possui. Contudo, o que Kant está afirmando é que apenas a espécie pode alcançar o desenvolvimento completo, não o indivíduo. Dito de outra forma, haveria uma contradição se o indivíduo não pudesse se desenvolver, mas não se ele não consegue alcançar a completude do desenvolvimento. Ora, se observarmos atentamente a posição de Kant, percebe-se que ela se apresenta da seguinte forma: ainda que o indivíduo singular não alcance a completude do desenvolvimento de suas disposições, mas somente a espécie, o progresso da espécie depende também do progresso dos indivíduos. Se fosse o caso de haver um progresso moral apenas na espécie, então a crítica de Herder seria válida e Kant sabe disso:

Pode-se ver como fim da Natureza: que toda criatura alcança a sua completa determinação, que todas as disposições da sua natureza se desenvolvem teleologicamente e, deveras, não apenas a espécie preenche a sua completa determinação, mas também cada indivíduo. Nos animais cada indivíduo alcança isso imediatamente, no homem apenas a espécie através de longas gerações, mas finalmente através dela cada indivíduo. (Refl. 1524, AA 15: 896. Tradução própria, negrito acrescentado)

A questão que se coloca inevitavelmente é sobre como esse progresso pode finalmente alcançar cada indivíduo. Para escapar da crítica de Herder, mas ainda assim, manter a tese central de sua filosofia da história, Kant aposta em um movimento dialógico entre 
o âmbito individual e o âmbito da espécie (social). Um movimento que deve ser mediado pela educação: "O destino final da espécie humana é a perfeição moral... mas como essa perfeição deve ser procurada e de onde deve ser esperada? De nenhum outro lugar exceto por meio da Educação." (V-Mo/Collins, AA 27.1: 470f.13-14, 05-07, tradução própria).

A espécie humana se distingue das outras espécies animais devido a sua faculdade racional. "Os animais cumprem sua determinação por si mesmos e sem que eles a conheçam” (Päd, AA 09: 445. tradução própria), pois "um animal já é tudo o que ele pode ser por meio de seu instinto; uma razão alheia já cuidou de tudo para ele."( Päd, AA 09: 441) Em outras palavras, as suas disposições naturais podem ser desenvolvidas integralmente em cada indivíduo na medida em que esse processo é governado pelo instinto. Já o ser humano, por outro lado, "precisa da sua própria razão. Ele não tem instinto e precisa por si mesmo fazer o plano de sua conduta. Mas por vir ao mundo em estado bruto e não estar imediatamente em condições de fazer isso: então outros precisam fazer isso por ele.” (Päd. AA 09: 441) Entra em cena assim a educação, pois é através dela que a espécie humana consegue extrair de si mesma, pouco a pouco, todas as suas disposições naturais. Desse modo, o desenvolvimento humano não ocorre biologicamente, mas é um processo pedagógico que precisa ser mediado institucional e culturalmente.

Nesse caso, o desenvolvimento do indivíduo (ontogênese) e o desenvolvimento da espécie (filogênese) são processos interrelacionados que se restringem mutuamente. Por um lado, a ontogênese retoma a filogênese, isto é, cada indivíduo precisa se apropriar dos conhecimentos e habilidades adquiridos e conservados pela geração anterior. Senão estaríamos condenados à eterna reinvenção da roda. Por outro lado, a filogênese depende do empenho dos indivíduos para que novos conhecimentos e 
habilidades sejam produzidos e os antigos preservados. Sem os indivíduos a filogênese não se realizaria. Por isso, a educação "pode apenas pouco a pouco dar um passo à frente e apenas por meio de que uma geração transmita às seguintes suas experiências e conhecimentos, esta novamente acrescentando algo e, assim, entregando às seguintes, pode surgir um conceito correto do modo de educar." (Päd, AA 09: 446) Por conseguinte, a educação é vista como um processo histórico infinitamente longo, no qual apenas a espécie pode atingir o seu desenvolvimento completo, mas sempre mediada também pelo progresso e empenho individual. Kant acredita que essa evolução pode permanecer por certo tempo estagnada, mas que jamais irá regredir completamente (Cf. Anth, AA 07: 324).

Por mais que Kant simpatizasse com a Revolução francesa, ele acreditava que o caminho adequado para o desenvolvimento político-jurídico de uma nação fosse a reforma e não a revolução. Isso significa que o progresso não deve ser esperado "de baixo para cima, mas de cima para baixo" (SF, AA 07: 92), através de reformas graduais realizadas pelos próprios governantes. Kant também não pensava que apenas "por meio da formação da juventude na instrução doméstica e, em seguida, nas escolas, desde as mais baixas às superiores, numa cultura intelectual e moral, reforçada pelo ensino religioso" (SF, AA 07: 92) se conseguisse formar bons cidadãos $\mathrm{e}$, consequentemente, se melhorasse gradualmente $\mathrm{o}$ conjunto do povo. Esses esforços são meritórios, mas por permanecem isolados são ineficientes enquanto executados a partir de esforços individuais. A unidade para esses esforços educativos somente pode ser esperada a partir de uma instância superior: o poder político soberano, o qual deveria colocar em ação um plano educacional unificado junto ao qual suas ações deveriam permanecer sempre em conformidade (Cf. SF, AA 07: 93). Por isso, Kant alerta que enquanto

Manuscrito - Rev. Int. Fil., Campinas, v. 37 , n. 1, p. 165 - 221, jan.-jun. 2014. 
os Estados empregarem todas as suas forças nos seus vãos e violentos propósitos de expansão, impedindo assim sem cessar o lento esforço da formação interior do modo de pensar dos seus cidadãos, subtraindo-lhes também todo o apoio em semelhante intento, nada há a esperar nesta esfera [a moralização]; pois requerse uma longa preparação interior para cada comunidade para a formação (Bildung) dos seus cidadãos. (IaG, AA 08: 26)

Assim caberia aos governantes realizar gradualmente a reforma no Estado procurando estabelecer uma constituição republicana que evite qualquer tipo de guerra ofensiva e que se integre e promova uma federação das nações; onde cada cidadão desfrute da máxima liberdade que esteja vinculada à máxima determinação dos seus limites; onde não haja impedimento em relação ao esclarecimento do povo (no sentido de uma censura ao uso público da razão); e ainda, onde haja um plano estatal de educação e desenvolvimento dos indivíduos.

Contudo, apesar de haver uma relação entre o bom governante (político moral) para o estabelecimento da constituição republicana, esse vínculo não deve ser tal que faça com que o bom funcionamento da constituição precise depender das qualidades individuais do governante, pois "a forma de regime ou a constituição do Estado é certamente má, precisamente porque faz depender a boa qualidade do governo da boa vontade de um só, quer ele seja bom ou não.” (Refl. 7637, AA 19: 490) A constituição republicana precisa ter a qualidade de evitar que o bom governo dependa necessariamente do arbítrio do soberano: a república deve ser governada pelas leis. A constituição republicana traz consigo um grande potencial pedagógico: da constituição do Estado "é que se deve esperar, acima de tudo, a boa formação moral de um povo)." (ZeF, AA 08: 366) Em outras palavras, a própria Constituição republicana do Estado atua como causa da boa formação moral de um povo. Ela funciona como um catalisador 
que, ao mesmo tempo, orienta os esforços singulares dos indivíduos de forma racional e também os organiza formalmente num sistema de comportamentos. Isso acaba fomentando o próprio esforço dos indivíduos em direção à sua formação moral. $\mathrm{Na}$ base desse pensamento está a ideia de que, na realidade, é a constituição que forma um povo, ainda que da perspectiva de justificação, o Estado seja visto como fruto de um pacto unionis civilis que dimana da vontade unida do povo, a qual por sua vez, não implica o assentimento factual dos indivíduos, mas promana da razão prática pura segundo uma lei moral. Nas palavras de Kant:

É uma simples ideia da razão, a qual tem no entanto a sua realidade (prática) indubitável: a saber, obriga todo o legislador a fornecer as suas leis como se elas pudessem emanar da vontade coletiva de um povo inteiro, e a considerar todo o súdito, enquanto quer ser cidadão, como se ele tivesse assentido pelo seu sufrágio a semelhante vontade. É esta, com efeito, a pedra de toque da legitimidade de toda a lei pública" (TP, AA 08: 297; Cf. Refl. 7734, AA 19: 503)

A existência de um Estado que exerça positivamente a coerção contra a violência recíproca dos cidadãos já fornece um "verniz moral" para a sociedade (ZeF, AA 08: 375n). Viver em sociedade segundo as leis de um Estado republicano não torna os indivíduos seres morais, mas gradualmente os educa segundo um modo de vida que não é baseado em ações ou ordens arbitrárias determinada por fins empíricos, mas por leis estabelecidas segundo os princípios da liberdade, dependência e igualdade da lei, o qual tem como fim o estabelecimento e a manutenção da liberdade. Tem-se assim o surgimento de um verniz moral, que não é por si mesmo um passo moral, mas que já constitui um passo para a moral. Isso indica que na filosofia da história, quando Kant fala do Estado, ele sempre acaba também se referindo à disposição moral do homem. 
O principal intuito do Estado deve ser preservar a liberdade e não a felicidade. Um governo que se colocasse a felicidade ou a benevolência como princípio seria um governo paternalista e despótico, pois trataria seus súditos como crianças, obrigando-lhes a se comportar de modo passivo, mantendo-os no estado de menoridade. A constituição de tal Estado "suprime a liberdade de todos os seus súditos, os quais, por conseguinte, não têm direito algum" (TP, AA 08: 291). Nesse sentido, Pinzani (2009, p. 240) aponta para o aspecto liberal da concepção kantiana da constituição do Estado, pois ela refutaria inclusive a versão paternalista do republicanismo clássico. $\mathrm{Na}$ constituição de um estado republicano, por outro lado, "fica ao arbítrio de cada um buscar a sua felicidade no caminho que lhe parecer melhor, contanto que não cause dano à liberdade legal geral, por conseguinte, ao direito dos outros cosúditos" (TP, AA 08: 298).

Mas um estado republicano que se empenhasse num projeto pedagógico para a educação moral de seus cidadãos também não estaria sendo paternalista? Uma resposta positiva parece surgir desta passagem:

Seria uma contradição que a comunidade política tivesse de forçar [zwingen] os seus cidadãos a entrar numa comunidade ética, pois esta última já no seu conceito traz consigo a liberdade quanto a toda coação. (...) Mas o legislador que quisesse orientar através de coação [durch Zwang] a constituição para fins éticos, então produziria efetivamente não só o contrário da constituição ética, mas também minaria e tornaria insegura a sua constituição política. (RGV, AA 06: 95f)

Todavia, essa passagem não é tão clara. O que está em jogo, por um lado, é a possibilidade de se constranger [zwingen] os cidadãos para entrarem numa comunidade ética, por outro, a possibilidade da própria constituição política de um Estado constranger os seus cidadãos para promoção de fins éticos. Ora, de fato, para o bom

Manuscrito - Rev. Int. Fil., Campinas, v. 37 , n. 1, p. 165 - 221, jan.jun. 2014. 
funcionamento do Estado de direito, é importante que as leis sejam administradas tendo em vista apenas a liberdade externa e as leis do direito. Contudo, nessa passagem Kant não está afirmando que, se um Estado tiver uma política educativa voltada para promoção da formação moral do cidadão, então isso promoverá contradição e insegurança política. É fundamental perceber que o que Kant está afirmando é que a institucionalização jurídica de fins éticos leva à contradição, mas não que o Estado deva se abster de oferecer um plano pedagógico integrado que promova uma educação para a liberdade, ou ainda, uma educação moral. Em outras palavras, o problema é exigir juridicamente, isto é, por constrangimento externo uma postura que somente pode ser interna. Mas, por outro lado, "toda comunidade política pode decerto desejar que nela se encontre também um domínio sobre os ânimos segundo leis de virtude; pois onde os seus meios de coação não chegam (...) ali operariam o requerido as disposições de ânimo" (RGV, AA 06: 95f). Nesse sentido, a leitura de Pinzani $(2009,292)$ de que "é impensável que o Estado pudesse agir na direção de tal moralização" não precisa ser a conclusão necessária da leitura dessa passagem da $R G V$, pois se o Estado não pode agir juridicamente nesse sentido, isto é, por via de coerção legal, não significa que ele não possa se utilizar de outros instrumentos institucionais para promover o progresso moral da disposição de ânimo dos seus cidadãos:

(...) se no ensino privado e público, se transformasse em princípio fazer assim [da virtude] uso constante (um método de inculcar os deveres que quase sempre se descurou), a moralidade dos homens bem depressa iria melhorar. Se a experiência histórica até agora ainda não quis provar o bom êxito das doutrinas da virtude, a culpa cabe precisamente ao falso pressuposto de que o móbil tirado da ideia do dever é em si mesmo demasiado sutil para a concepção comum, ao passo que, pelo contrário, a ideia mais grosseira, derivada de certas vantagens a esperar neste mundo e até num

Manuscrito - Rev. Int. Fil., Campinas, v. 37 , n. 1, p. 165 - 221, jan.-jun. 2014. 
mundo futuro (sem atender à própria lei como móbil), atuaria com mais força sobre o ânimo; e ao fato de até agora se ter dado a preferência para o princípio da educação e da pregação no púlpito, à ânsia pela felicidade, em confronto com aquilo de que a razão faz a condição suprema , isto é, merecer ser feliz. (TP, AA 08: 288. 04$18)^{15}$

O conceito de uma educação moral que abdica do conceito de felicidade indica a saída para crítica do paternalismo, pois, nesse caso, não se está orientando segundo algum conceito de felicidade, mas se tem como fundamento e como meta o conceito de liberdade. Seria uma educação que abstrairia das peculiaridades e preconceitos de um determinado povo ou comunidade e buscaria conduzir a espécie humana para a sua destinação: o

${ }^{15}$ Também sobre isso: "Enquanto porém, os Estados empregarem todas as suas forças nos seus vãos e violentos propósitos de expansão, impedindo assim sem cessar o lento esforço da formação interior do modo de pensar dos seus cidadãos, subtraindo-lhes também todo o apoio em semelhante intento, nada há que esperar nesta esfera; pois requer-se uma longa preparação interior de cada comunidade para a formação (Bildung) dos seus cidadãos. Mas todo o bem, que não está imbuído de uma disposição de ânimo (Gesinnung) moralmente boa, nada mais é do que penúria e aparência coruscante."(IaG, AA 08: 26); "Os pais educam os filhos para o mundo presente, ainda que seja corrupto. (...) e os príncipes consideram os próprio súditos apenas como instrumento para os seus propósitos. Os pais cuidam da casa, os príncipes do Estado. Uns e outros deixam de se propor como fim último o bem geral e a perfeição a que está destinada a humanidade e para a qual esta tem as disposições. O estabelecimento de um projeto educativo deve ser executado de modo cosmopolita." (Päd, AA 09: 447f.); e "A educação é privada ou pública. Esta última se refere às informações, e pode permanecer sempre pública. A prática dos preceitos fica reservada a primeira. Uma educação pública completa é aquela que reúne, ao mesmo tempo, a instrução e a formação moral.” (Päd, AA 09: 452. 13-17).

Manuscrito - Rev. Int. Fil., Campinas, v. 37 , n. 1, p. 165 - 221, jan.jun. 2014. 
desenvolvimento da liberdade. Essa liberdade só pode ser alcançada por uma comunidade quando ela passa por um processo educativo que é tanto negativo quanto positivo. O negativo educa e disciplina o indivíduo para que ele não seja dominado por suas inclinações sensíveis e por preconceitos. Já o processo educativo positivo ensina as crianças a viverem segundo máximas, algo que a vivência sob um Estado republicano por si só também já fomenta e, em seguida, educa-os de forma a lhes mostrar com toda a clareza o valor da lei moral e da ideia do direito dos homens.

"Que a virtude pode e deve ser ensinada é algo que decorre do facto de ela não ser inata” (MS, AA 06: 477. 13-14). E o ensino deve ocorrer não apenas no ensino privado, mas também no ensino público. Em outras palavras, Kant aceita que o Estado assuma como uma de suas atribuições a execução de um plano conjunto para uma instrução pública da virtude. Ela não seria apenas uma educação cívica, pois não está em questão apenas o ensino dos deveres jurídicos, mas também o ensino dos deveres de virtude. Além disso, o ensino não se daria com base nas consequências das ações, isto é, em mostrar ao aluno as consequências boas da virtude e as consequências ruins do vício, mas em apontar para os princípios da ação, os quais sempre devem estar fundados na lei moral e na autonomia da vontade (Cf. MS, AA 06: 482f. 30-08). Isso não compromete o aspecto liberal do pensamento kantiano por dois motivos: primeiro, por que os deveres de virtude não estão baseados no princípio material da felicidade, mas na lei moral que é universal; segundo, o Estado não coagiria os indivíduos a cumprirem os deveres de virtude, isto é, as ações segundo os deveres de virtude não deveriam ser exigidas pelo direito positivo, mas o Estado apenas ensinaria os deveres de virtude, deixando aos indivíduos o direito de realizá-los da forma que melhor lhes convier, desde que cumprissem os deveres jurídicos. Naturalmente que a legitimidade desse ensino público da virtude depende da 
forma como essa educação é conduzida, pois essa forma pode comprometer profundamente o projeto. Contudo, esse é um tema que merece ser abordado num artigo independente.

\section{SOBRE O SIGNIFICADO E O CARÁTER DE UMA VIRTUDE MORAL}

$\mathrm{Na}$ seção anterior mostrou-se que a filosofia política kantiana assume o ensino público da virtude como um meio para fazer com que a política possa se aproximar gradativamente do ideal de uma respublica noumenon. Cabe perguntar agora quais seriam os principais traços dessa virtude que se espera alcançar por meio da educação e de como ela pode ser pensada no contexto da filosofia kantiana.

No livro Königlicher Völker, Höffe (2001, 112s) apresenta uma distinção bastante esclarecedora. Segundo ele, podemos encontrar em Kant duas legislações (legislação ética e a legislação jurídica, ou ainda, a exigência de deveres jurídicos e deveres éticos/de virtude) e duas formas de legalidade, isto é, a forma como o sujeito se relaciona com aquelas duas legislações, a saber, a legalidade e a moralidade. Ao cruzarmos ambas as categorias surgem quatro possibilidades:

i. Legalidade jurídica: o sujeito cumpre a legislação jurídica (deveres jurídicos) simplesmente por (segundo o fundamento de determinação do arbítrio) uma inclinação sensível, tal como o medo de ser punido ou pelo desejo de ser reconhecido como um cidadão honrado;

ii. Legalidade ética: o sujeito cumpre os mandamentos éticos por inclinações sensíveis, tal como por medo de Deus ou de represálias sociais;

iii. Moralidade jurídica: O sujeito cumpre os deveres jurídicos por respeito à ideia de direito.

Manuscrito - Rev. Int. Fil., Campinas, v. 37 , n. 1, p. 165 - 221, jan.-jun. 2014. 
iv. Moralidade ética: $\mathrm{O}$ sujeito cumpre seus deveres éticos por respeito à lei e à ideia de dever moral.

Kant jamais apresenta claramente essas quatro possibilidades, mas elas podem ser derivadas sistematicamente das definições oferecidas por ele. A terceira possibilidade, a moralidade jurídica é de particular interesse para o tema aqui em questão. A terceira possibilidade é inclusive nomeada explicitamente no início da Doutrina das Virtudes (Cf. MS, AA 06: 390), mas Höffe não a apresenta como sua resposta final ao progresso da história. $\mathrm{Na}$ verdade, ele acaba defendendo o conceito de uma moralidade das instituições e não de uma boa vontade ou de uma melhoria na disposição dos indivíduos. Nesse caso, ele opta por defender a tese de um progresso jurídico-moral das instituições de forma que elas consigam cada vez mais assegurar os direitos naturais dos cidadãos. Porém, seguindo a alternativa mencionada, mas não desenvolvida por Höffe, Pinzani sugere que o progresso jurídico abarcaria algo que poderia ser chamado de virtude política, ou seja, uma atitude que corresponderia à moralidade jurídica, a saber, a possibilidade de se obedecer às normas jurídicas também por puro respeito à lei. Esse seria um considerável acréscimo à legalidade jurídica, na medida em que se ultrapassa o mero cumprimento da lei pelo medo de alguma sanção externa. Ao passo que isso se tornasse um hábito ou uma "segunda natureza”, o indivíduo possuiria virtude.

Essa virtude política teria duas características essências: primeira, ela distingue-se daquilo que se entende por virtude cívica na tradição republicana, pois ela não apresenta uma sustentação do cidadão a um determinado Estado em particular, mas sim a um mandamento da razão (PINZANI, 2009, 302s). A segunda característica dessa virtude é que ela se restringe ao campo do direito, isto é, ela não implica nenbuma melhora na disposição de animo do indivíduo singular, ou ainda, em Kant "as virtudes políticas servem apenas para a construção de uma possível 
constituição republicana perfeita. Por isso, seu fim (...) é imanente à política e não faz indicação à esfera moral” (PINZANI, 2009, 298). Em suma, a posição de Pinzani é a de que o progresso na história se refere apenas ao desenvolvimento do direito, o qual se dá basicamente pelo desenvolvimento e melhoramento das instituições. Nesse contexto, pode surgir a virtude política, a qual é um ganho, mas não é por si mesma necessária para a própria criação de instituições republicanas. Essa virtude seria necessária para que se pudesse alcançar uma perfeita constituição republicana, mas não para a fundação de uma república, já que isso, em sua opinião, seria possível inclusive para um povo de demônios. Contudo, segundo ele, o ganho representado pela virtude política permanece no âmbito da legalidade: do desenvolvimento da liberdade externa, a qual pode possuir um papel pedagógico em relação ao indivíduo, de forma que ele se acostume a seguir as leis por elas próprias. Ainda que a virtude política não precise ser desenvolvida em função da virtude ética, ela poderia servir como uma espécie de “antecâmara” para essa. Em outras palavras, as instituições são précondição para a virtude política, a qual, por sua vez, é pré-condição para a virtude ética, sem que haja uma relação de instrumentalização ou de dependência da primeira em relação à segunda e assim sucessivamente (Cf. PINZANI, 2009, 304).

Discorda-se aqui a respeito da segunda característica apresentada acima, pois estritamente compreendido, o direito não tem legitimidade para demandar um agir orientado pelo "respeito", pois, por princípio, ele tem a ver apenas com o âmbito externo da ação. Nesse caso, sem a legitimidade para demandar respeito, não seria possível a constituição de uma república. Em outras palavras, a realização do direito (não no sentido de sua legitimidade, mas de sua contínua progressão histórica) depende de um respeito à lei, o qual o próprio direito não pode impor, isto é, para que ocorra a constante reforma das instituições estatais e supraestatais é 
necessário que os políticos se guiem por um princípio que não pode ser posto e exigido pelo próprio direito. É pelo reconhecimento da necessidade de uma atitude interna relativa a disposição de ânimo do agente que Kant afirma com relação à política: "todas as máximas que necessitam da publicidade (para não fracassarem no seu fim) concordam simultaneamente com o direito e a política" (ZeF, AA 08: 386. 12-13). Ao se pensar num critério que envolva uma avaliação de máximas, já se indica que se está fora daquilo que cabe ao domínio estrito do direito, pois o direito dá lei apenas às ações, já a ética dá lei para as máximas das ações (Cf. MS, AA 06: 388. 3233), ou ainda, apenas a ética possui um fim que é simultaneamente dever (Cf. MS, AA 06: 381. 04-24; 389. 12-16) e apenas o cumprimento dos deveres de virtude constitui um mérito (Cf. $M S$, AA 06: 390. 18-19). Ora, todos esses elementos estão presentes na caracterização de Kant a respeito da "moralidade jurídica":

Se bem que a conformidade das ações ao direito (ser um homem respeitador da legalidade) não constitua algo meritório, é meritória sim a conformidade à máxima de tais ações como deveres, isto é, o respeito pelo Direito. Pois que, deste modo, o homem propõe-se como fim seu o direito da Humanidade ou também dos homens e amplia assim o seu conceito de dever para além do conceito daquilo que é devido (officium debiti): por que alguém, com base no seu direito, pode muito bem exigir de mim ações conformes à lei, mas não que esta contenha ao mesmo tempo o móbil dessas ações. (MS, AA 06: 390f. 30-03. Negrito acrescentado) ${ }^{16}$

${ }^{16}$ Também: “A Ética tem, decerto, também os seus deveres peculiares (por exemplo, os deveres para consigo mesmo), mas, não obstante, tem também deveres comuns com o Direito, só que não o modo de obrigação. Pois realizar ações apenas porque são deveres e converter em móbil suficiente do arbítrio o próprio princípio do dever, qualquer que seja a sua proveniência, constitui a especificidade da legislação ética. Há pois, decerto, muitos deveres éticos diretos, mas a legislação interior faz

Manuscrito - Rev. Int. Fil., Campinas, v. 37 , n. 1, p. 165 - 221, jan.-jun. 2014. 
Contudo, por outro lado, essa "moralidade jurídica" tomada aqui como base para a constituição de uma República também não pode ser uma virtude ética estrito senso, tal como tematizada na Doutrina das virtudes. A virtude ética se caracteriza exatamente como uma conquista individual, intransferível, incomunicável e cognoscitivamente incerta (Cf. MS, AA 06: 392f.; EaD, AA 08: 329f), ou seja, a partir de uma perspectiva ética não se pode legitimar uma teoria sobre um progresso social, pois a virtude deve ser conquistada através dos méritos próprios do agente. Quanto maior as dificuldades superadas, tanto maior o valor da virtude (Cf. MS, AA 06: 391; $K p V$, AA 05: 156). Nessa lógica, para que a virtude pudesse brilhar com maior intensidade, tanto mais dificuldades deveriam ser enfrentadas, quer dizer, as circunstâncias no mundo deveriam ser cada vez mais desfavoráveis para o agir moral para que ela tivesse a chance de se destacar ainda mais. Esse destaque se refere à necessidade da pureza da vontade, isto é, de que a ação seja realizada eminentemente por puro respeito à lei moral e sem qualquer interferência de interesses empíricos.

Além disso, mas não com menor importância, cabe também ressaltar que são dois os fins dos deveres de virtude, a saber, a perfeição própria e a felicidade alheia (Cf. MS, AA 06: 385). Colocar a felicidade alheia como o fim da política seria tropeçar na crítica de paternalismo, a qual uma República deve escapar. Já a perfeição própria somente é alcançada por meio de um processo autônomo e qualquer tentativa de estabelecer uma legislação externa com relação a isso ultrapassaria a legitimidade de atuação do Estado. Dessa forma, a moralidade jurídica não tem como fim os deveres de virtude, mas apenas a própria ideia de um direito

também de todos os restantes deveres éticos indiretos.” (MS, AA 06: 220221. 32-03)

Manuscrito - Rev. Int. Fil., Campinas, v. 37 , n. 1, p. 165 - 221, jan.-jun. 2014. 
puro. Dito de outra forma, não apenas as leis do direito positivo de um determinado Estado, mas os princípios metafísicos do Direito devem constituir o móbil da moralidade jurídica. Claro que indiretamente é possível compreender a moralidade jurídica como fomentando a realização dos deveres de virtude éticos, pois garantindo a cada um seu direito, não apenas segundo a letra, mas também segundo o espírito da lei, permite-se que os membros da sociedade possam realizar mais facilmente seus planos de vida (segundo seus conceitos de felicidade) e se dedicarem ao seu contínuo aperfeiçoamento moral.

Note-se que a moralidade jurídica possui um fim e ela não se refere apenas à regulamentação da liberdade exterior, como faz o direito. Por outro lado, o seu fim não é propriamente um fim da virtude ética em sentido estrito. De todo modo, o fim da moralidade jurídica fortalece a realização dos princípios da doutrina do direito e garante a possibilidade de que os fins da virtude se realizem adequadamente. Tendo isso em vista, defende-se aqui que essa atitude de uma "moralidade jurídica" poderia ser caracterizada como uma virtude moral, a qual deve ser pensada a partir da articulação entre direito e ética, assim como a própria categoria de moral, tal como apresentada na Metafísica dos costumes. Ora, o próprio contexto teleológico prático no qual ser insere a filosofia kantiana da história e da política já indica que essa virtude moral está estreitamente vinculada ao elemento intermédio da cultura da disciplina. Kant define a cultura $d a$ disciplina (Zucht/Disziplin) como a "libertação da vontade em relação ao despotismo dos desejos, pelos quais nós nos prendemos a certas coisas da natureza e somos incapazes de escolher por nós mesmos" (KU, AA 05: 432. 05-07). Essa cultura, que se apresenta como o fim último da natureza, possui duas características: por um lado, ela ainda permanece dentro do sistema da natureza; por outro, ela é 
determinada em função de algo que está fora da natureza, no âmbito do suprassensível, a saber, o fim terminal.

Pertencer ao sistema da natureza como elemento último significa que a cultura da disciplina pode ser pensada, ainda que em sentido negativo, como estando dentro de um contexto de fins que existe na natureza e que, por isso, pode ser por ela fomentada. Em outras palavras, é possível pensar, por exemplo, seja em uma Natureza que promova o progresso através do antagonismo das disposições humanas, a sociabilidade insociável, seja numa "pedagogia”, institucional ou não, que promova o fim último, a cultura da disciplina e uma educação moral. Além disso, ela pode ser, de certa forma, percebida como estando em progresso, ainda que isso não possa ser determinado de um modo absolutamente preciso. Nesse sentido, quanto menos indivíduos estiverem dominados por alguma paixão ou descumprirem a lei quando não estiverem sendo vigiados, tanto mais aquela sociedade pode ser pensada como estando em acordo com o fim último da natureza. Ou ainda, quanto mais os indivíduos respeitarem as leis do seu Estado e o direito cosmopolita, independente de policiamento do Estado, tanto menos os indivíduos estarão agindo por medo de serem punidos e, por conseguinte, tanto mais aquela sociedade estará conforme ao fim último da natureza.

Que a cultura da disciplina seja determinada a partir de um elemento suprassensível significa, por sua vez, que ela se orienta e se legitima com referência à legislação moral, ou seja, que se encontra determinada pelo conceito daquilo que o indivíduo e a espécie humana devem ser: sempre simultaneamente um fim em si mesmo. A partir dessa orientação ético-moral, a cultura da disciplina não pode se contentar apenas com uma sociedade em que o direito seja legítimo e funcione adequadamente, mas é preciso que o próprio Estado seja posto em contínua reforma no sentido de se aproximar constantemente do ideal de um República noumenon e que os 
indivíduos não apenas cumpram a lei "ao pé da letra”, mas também segundo o seu "espírito". ${ }^{17}$ Nesse caso, o progresso na história e na política é pensado também como um aumento do respeito mútuo entre os indivíduos, de modo que não se trate simplesmente de respeitar a liberdade externa de outrem, mas também de protegê-la e fomentá-la, ou seja, de uma sociedade em que os indivíduos ajam cada vez mais como indivíduos virtuosos.

A cultura da disciplina não pertence propriamente nem ao direito nem à ética, mas é um conceito da faculdade de julgar teleológica moral que em caso de necessidade deve poder ser ocasionalmente ajustado a cada parte de ambos. ${ }^{18}$ Ora, segundo a perspectiva do direito não importa se os indivíduos agem por medo, interesse ou respeito, mas simplesmente que eles façam o que é devido. Segundo a perspectiva da ética, o que entra em questão não são as consequências da ação, mas a máxima a partir da qual se realizou tal ação. Já a partir da perspectiva da história universal e da política o que está em questão é, de um lado, a

${ }^{17}$ Sobre o conceito de "letra da lei" e "espírito da lei" conferir: "Pode-se dizer de cada ação conforme à lei, que, contudo, não ocorreu por causa da lei, que ela seja moralmente boa apenas segundo a letra, mas não segundo o espírito (segundo a disposição)." (KpV, AA 05: 72n); "[Se a virtude não fosse apresentada em sua completa pureza, então] tudo não passaria de pura hipocrisia, a lei seria odiada ou até desprezada, ainda que fosse seguida em proveito próprio. A letra da lei (legalidade) seria encontrável em nossas ações, mas o espírito das mesmas de modo algum em nossas disposições (moralidade).” (KpV, AA 05: 152. 05-09); Também: $R G V$, AA 06: 30.

${ }^{18} \mathrm{Na}$ introdução da KU, Kant afirma que a faculdade do juízo pode ser eventualmente vinculada, conforme a necessidade, seja à natureza seja à liberdade. Seguindo essa sugestão, também pode-se pensar que a faculdade de julgar teleológica poderia, dependendo do caso, ser ajustada com maior adequação seja à ética, seja ao direito, dependendo da necessidade provocada pelo objeto e questão. Sobre isso conferir Klein, 2013c.

Manuscrito - Rev. Int. Fil., Campinas, v. 37 , n. 1, p. 165 - 221, jan.jun. 2014. 
possibilidade dos indivíduos agirem cada vez mais por respeito ao direito e à dignidade humana (atitude que se aproxima da ética, pois leva em conta a disposição de ânimo do indivíduo), e, de outro lado, de se criar mecanismos político-institucionais que estimulem e promovam tal espécie de comportamento (aspecto que se aproxima do direito na medida em que se pense em formas de institucionalizar a promoção de determinados comportamentos). Em outras palavras, para a filosofia da história e para a política está em questão a possibilidade de se pensar mecanismos que promovam um aumento gradativo e contínuo da cultura da disciplina, algo que da perspectiva do próprio discurso da história universal e da política poderia ser denominado de virtude moral.

Sendo a virtude moral um conceito pensado a partir da faculdade de julgar reflexionante teleológica e que se desenvolve exatamente no campo intermédio entre a ética e o direito, isso justificaria a sua referência a uma boa disposição moral do agente, sua boa vontade, bem como sua vinculação a estímulos e considerações que não são estritamente éticas. Nesse sentido, à semelhança da virtude ética, ela se mostra como um ideal que deve ser perseguido, mas que jamais se pode estar certo de a possuir (Cf. $M S$, AA 06: 409. 21-34). A virtude não é nem uma habilidade, nem pode ser adquirida por meio de um hábito prolongado, adquirido pelo exercício (Cf. MS, AA 06: 383f. 33-03). Contudo, ela pode se tornar um hábito livre, não enquanto "uma conformidade que se converteu em necessidade por repetição frequente da ação”, mas pela constância "em determinar-se a agir pela representação da lei" (MS, AA 06: 407. 08-14). Por outro lado, a virtude moral, afastando-se da virtude ética e se aproximando do direito, não exigiria pureza de intenção. Nesse caso, é possível que uma série de outras considerações possam estar presentes no momento do agir e atuem para fortalecê-lo, ou mesmo para moderá-lo segundo a contingência das situações. Dito de outra forma, é no horizonte de 
uma teleologia prática que se pode inserir, em diferentes graus, um discurso sobre "a aparência moral permitida" (a decência, o decoro e a cortesia: Cf. $A n t h$, AA 07: 151f; $M S$, AA 06: 473f; $M A M$, AA 08: $113 ; K r V$, B 776), a reflexão pedagógica de uma educação para a moralidade e um discurso sobre o progresso moral do gênero humano, bem como o discurso da prudência política, que qualifica "a bondade da pomba" com "a esperteza da serpente". Nesse sentido, a virtude moral assume o esforço explícito em respeitar a humanidade, tanto na sua pessoa quanto na pessoa dos outros, mesmo que tal intento pudesse ser inicialmente vinculado à "aparência moral permitida". Como Kant escreve na Antropologia: “A natureza implantou sabiamente no homem a propensão a se deixar de bom grado enganar, quer para salvar a virtude, quer para conduzi-lo a ela." (Anth, AA 07: 151) Ou ainda, "enganar, porém, o enganador que há em nós mesmos, enganar a inclinação é, por sua vez, voltar a obedecer à lei da virtude, não engano, mas inocente ilusão de nós mesmos." (Anth, AA 07: 151)

Contrariamente à leitura aqui defendida, a saber, do desenvolvimento de uma virtude moral como condição para a fundação de uma República e de seu contínuo aperfeiçoamento, poder-se-ia mencionar a seguinte passagem do Conflito das faculdades:

9. Que lucro trará ao gênero humano o progresso para o melhor? Não uma quantidade sempre crescente de moralidade na disposição de ânimo, mas um aumento dos produtos da sua legalidade em ações conformes ao dever, sejam quais forem os motivos que as ocasionem; i.e. nos atos bons dos homens, que se tornarão sempre mais numerosos e melhores, por conseguinte, nos fenômenos da condição moral do gênero humano, é que se poderá situar apenas o ganho (resultado) da sua refundição em vista do melhor. (SF, AA 07: 91)

Manuscrito - Rev. Int. Fil., Campinas, v. 37 , n. 1, p. 165 - 221, jan.-jun. 2014. 
Essa passagem seria quase uma refutação à tese aqui defendida se não fosse pelo contexto, que a ressignifica. $\mathrm{O}$ fenômeno ao qual Kant se refere é o signo histórico da participação desinteressada dos expectadores da revolução francesa que vale como um "signum rememorativum, demonstrativum, prognosticon" do progresso para o melhor. Pode-se no mínimo questionar a validade e restrição desse argumento em favor de uma leitura meramente jurídico-legal, já que esse fenômeno pretende demonstrar "um caráter moral do gênero humano no seu conjunto e, ao mesmo tempo (por causa do desinteresse), um seu caráter moral, pelo menos na disposição, caráter que não só permite esperar a progressão para o melhor, mas até constitui já tal progressão" (SF, AA 07: 85). Visto que nessa passagem o signo histórico é vinculado a um caráter moral na disposição (Anlage), pode-se assumir legitimamente que esse argumento seria uma variação da expressão da lei moral através do sentimento de respeito, como analogamente apresentado na GMS e na $K p V$. Essa semelhança com a ética também pode ser apontada em outra passagem:

A causa moral aqui interveniente é dupla: primeiro, é a do direito de que um povo não deve ser impedido por outros poderes de a si proporcionar uma constituição civil, como ela se lhe afigurar boa; em segundo lugar, a do fim (que é ao mesmo tempo dever), de que só é em si legítima e moralmente boa a constituição de um povo que, por sua natureza, é capaz de evitar, quanto a princípios, a guerra ofensiva - tal não pode ser nenhuma outra a não ser a constituição republicana, pelo menos segundo a ideia. (SF, AA 07: 85f.)

Em outras palavras, o sentimento de entusiasmo pertence à constelação da teoria moral kantiana na medida em que, em primeiro lugar, aponta para o direito de um povo de se autodeterminar; em segundo lugar, diz respeito à legitimidade ética do fim escolhido por tal povo, que não é apenas legítimo por ter sido 
escolhido por ele, mas por que o fim escolhido é ele mesmo um dever.

Nesse caso, a aparente restrição ao progresso estritamente jurídico-legal do agir humano no Conflito das faculdades pode ser explicada pelo caráter polêmico do escrito. Quer dizer, "não devemos também a nós prometer excessivamente a propósito dos homens no seu progresso para o melhor para, com razão, não incorrermos no escárnio do político, que de bom grado tomaria esta esperança pelo devaneio de uma cabeça exaltada.” Mas, a acusação de devaneio seria legítima se Kant quisesse "ampliar o fundamento moral do gênero humano", pois para isso "exigir-se-ia também uma espécie de nova criação (influxo sobrenatural)" ( $S F$, AA 07: 92). Mas não é devaneio algum representar-se a possibilidade de esclarecimento do fundamento moral do gênero humano, o que teria como consequência a aproximação constante ao ideal de República. Essa aproximação é mesmo um “dever do chefe do Estado" (SF, AA 07: 92n). Kant aposta na reforma constante do Estado em direção ao ideal de República, mas como o Estado pode ter um chefe que cumpra seu dever? Volta-se assim novamente ao mesmo problema da sexta proposição da IaG: a necessidade de um chefe dotado de boa vontade, ou ainda, que seja esclarecido quanto ao seu fundamento moral. Logo a seguir Kant indica novamente sua solução: uma educação promovida pelo poder político soberano, a qual, promovendo uma educação para a virtude moral, faz com que o Estado "avançasse permanentemente para o melhor” (SF, AA 07: 92f). ${ }^{19}$ Também entram aqui

${ }^{19}$ Claro que aqui sempre entra a questão de como se pode quebrar esse aparente círculo vicioso: "[Rousseau] supunha que o homem é bom por natureza (como ela se deixa transmitir); porém de um modo negativo, quer dizer, ele não é por si mesmo e deliberadamente mau mas apenas pelo risco de ser contaminado e corrompido por mau exemplos ou guias ineptos. Mas porque para isso são por sua vez necessários homens bons,

Manuscrito - Rev. Int. Fil., Campinas, v. 37 , n. 1, p. 165 - 221, jan.jun. 2014. 
considerações a cerca de uma concordância com a intenção da providência. Mas, como sempre nos textos dedicados a história, essas considerações devem ser lidas na perspectiva da teleologia moral, isto é, no sentido de que a natureza humana e a Natureza podem ser compreendidas como cooperando com seus fins da razão prática pura, o que permite esperar que eventualmente surjam indivíduos dotados de boa vontade que se tornem governantes e legisladores, os quais, por sua vez, podem interromper o ciclo do poder e do moralismo político e iniciem o ciclo do direito e da política moral.

De todo modo, da perspectiva de um observador externo, tal como a de um jurista-político que age segundo o mote de que "importa tomar os homens como são e não como ignaros do mundo ou benévolos fantasistas sonhando o que deviam ser" (SF, AA 07: 80), "pouco a pouco, diminuirá a violência por parte dos poderosos e aumentará a docilidade quanto às leis. Haverá por ventura, na sociedade mais beneficência e menos rixas nos processo, maior confiança na palavra dada". Claro que de um ponto de vista teórico fica em aberta a questão de isso ocorrerá "quer por amor da honra, quer por interesse pessoal bem entendido"? (SF, AA 07: 92)

Assim, falar de uma virtude moral a partir de uma perspectiva teleológica prática permite pensar em um modo no qual

que precisam eles mesmos ser educados e dos quais não existe nenhum que não tenha em si perversidade (inata ou adquirida), o problema da educação moral de nossa espécie permanece sem solução, não meramente quanto ao grau, mas quanto à qualidade do princípio, porque nela uma má propensão inata pode ser muito bem censurada e mesmo até refreada, mas não exterminada pela razão humana universal.” (Anth, AA 07: 327) Não é por isso de se admirar que "Este problema é ao mesmo tempo o mais difícil e o que mais tardiamente é resolvido pelo gênero humano" (IaG, AA 08: 23)

Manuscrito - Rev. Int. Fil., Campinas, v. 37 , n. 1, p. 165 - 221, jan.jun. 2014. 
a perspectiva fenomênica e a noumênica se relacionem. Não se precisa transformar o direito em ética, nem a ética em direito para se pensar legitimamente em um âmbito moral que seja ao mesmo tempo mais do que a mera legalidade jurídica e menos do que uma moralidade ética. Nesse sentido, tal como se defendeu aqui, a posição política kantiana não implica:

1. na substituição do governo das leis por um governo de homens de suposta ou reconhecida boa vontade;

2. que fins éticos sejam transformados em lei, ou ainda, que o direito se proponha a investigar e punir os agentes devido às suas intenções, implantando assim algo como um "terrorismo ético" por parte do Estado;

3. que o único e principal critério para escolha de representantes deva ser realizada de acordo com o seu caráter, isto é, com a sua suposta integridade moral, pois, segundo a ética kantiana, não é possível avaliar adequadamente o caráter de um indivíduo. Ele poderia forjar uma série de situações em sua vida privada, usando-as como marketing para alcançar o poder e até mesmo justificar ações ilegais. Daí surge a "falácia política" comum hodiernamente: do político moral como a figura do "bom pai e marido", do "bom amigo", do "bom chefe", ou ainda a do "cristão bom e devoto". Por outro lado, a teoria política kantiana exige:

1. que o político seja um político moral, isto é, que seja dotado de boa vontade na realização da ideia do direito, o que se apresenta como condição para a criação e desenvolvimento de um República;

2. que os princípios morais, isto é, que uma virtude moral no sentido de um esclarecimento moral em direção à autonomia sejam ensinados nas escolas com o objetivo de estimular, preservar e fortalecer a República. Isso se deve a dois aspectos: a) em todas as formas de Estado, mas especialmente na democracia representativa, os representantes são escolhidos no próprio povo e pelo próprio 
povo; b) o próprio povo deve ser motivado pela ideia do direito para que não aceite que uma minoria, ou mesmo que outros povos sejam tratados simplesmente como meios/objetos pela política do seu Estado.

Ora, isso pode ser coordenado legitimamente no âmbito do discurso reflexionante prático da história universal vinculado com a política. Nesse nível é possível tratar de um progresso compartilhado intersubjetivamente ao mesmo tempo em que se toma como referencial algo que ultrapassa a mera letra da lei e se projeta em direção ao respeito pela humanidade e pela justiça, "corporificando-se" tanto em instituições, quanto em formas de conduta que possam ser pedagogicamente promovidas. ${ }^{20}$

$* * \%$

A partir do que se defendeu acima, percebe-se que Kant possui um liberalismo e um republicanismo sui generis. ${ }^{21}$ Ele permanece um liberal político na medida em que não concorda com a intervenção estatal em assuntos que dizem respeito ao conceito de felicidade, que deve ser escolhido individualmente por seus cidadãos, visto não se poder ser universalizada. ${ }^{22}$ Nesse

${ }^{20}$ Nesse sentido, ainda que a partir de argumentos e de textos distintos, chega-se a uma conclusão semelhante a de Willaschek (2005, p. 202s). ${ }^{21}$ Também Berten (2007) sustenta que a teoria política de Kant se apresenta como um republicanismo de espécie bem distinta. Contudo, os argumentos de Berten não se focam na realização da atividade política, mas nos próprios princípios que legitimam Estado de direito.

${ }^{22}$ Porém, também é importante lembrar que a noção de felicidade é entendida como vinculada ao projeto de vida que o indivíduo assume segundo suas preferências, e não com as condições mínimas para sobrevivência e cidadania, pois, se Kant acredita que é legítimo que o Estado intervenha em assuntos de educação moral e cívica dos seus

Manuscrito - Rev. Int. Fil., Campinas, v. 37 , n. 1, p. 165 - 221, jan.jun. 2014. 
sentido, há uma rigorosa separação entre o direito e a ética, no sentido de que apenas a liberdade externa pode ser objeto de regulamentação jurídica e coercitiva. Por outro lado, a legitimidade do Estado em fomentar uma educação para a virtude aproxima Kant do pensamento republicano. Mas essa aproximação ao republicanismo também precisa ser feita de modo cauteloso, pois a virtude presente na filosofia política kantiana não visa a um bem comum que os cidadãos deveriam guardar, nem diz respeito a um determinado Estado, mas se refere a uma atitude universal que todos os seres humanos deveriam fomentar: a republicanização, o cumprimento das leis e a disposição constante de melhorar a legislação, tanto em um nível nacional, quanto internacional segundo os princípios metafísicos da doutrina do direito.

Essa virtude moral, enquanto fim de um plano pedagógico implementado de modo integrado pelo Estado, se mostra como condição para que o próprio Estado se constitua e se mantenha como uma República e para que ele continuamente se reforme em direção à criação de instituições que estejam cada vez mais de acordo com o ideal de respublica noumenon. Esse conceito extremamente particular de uma virtude moral é o resultado de uma convergência conceitual dos domínios da ética e do direito que se desenrolam no campo da faculdade reflexionante teleológica. Nesse horizonte sistemático, pode-se assumir a necessidade de uma educação moral para a autonomia, sem que se precise ou possa institucionalizar essa virtude nos códigos legais e vinculá-la a uma coação externa. $\mathrm{O}$ projeto de uma educação para a autonomia não fere a separação jurídico-institucional entre os domínios do direito e da ética, ele evita uma juridificação da ética, assim como uma

cidadãos, também não é estranho à estrutura de sua teoria aceitar uma interferência estatal para as garantias materiais mínimas para o exercício da cidadania.

Manuscrito - Rev. Int. Fil., Campinas, v. 37 , n. 1, p. 165 - 221, jan.jun. 2014. 
eticização do direito. Para Kant, apenas através de um processo dialógico entre os indivíduos e as instituições, entre ética e direito, o gênero humano pode quebrar o circulo vicioso de uma estagnação político-moral, assim como escapar do risco de um regresso ao infinito para alcançar a realização de um verdadeiro Estado republicano, assim como de uma Federação de Repúblicas junto com a verdadeira paz.

\section{REFERÊNCIAS}

BRANDT, R. "Antwort auf Bernd Ludwig: Will die Natur unwiderstehlich die Republik?” In: Kant-Studien, n.88 (1997), pp. 229-237.

BERTEN, A. "A Compatibilidade do Republicanismo Kantiano com o Modelo do Contrato Social”. In: L. R. dos Santos; J. G. André (Coord.) (2007), pp.13-42.

CASTILLO, M. "Moral und Politik: Mißhelligkeit und Einhelligkeit”. In: O. Höffe (Hrsg.) (2004), pp. 195-220.

GERHARDT, V. (Hrsg.) Kant im Streit der Fakultäten. Berlin/New York: Walter de Gruyter, 2005.

GUYER, P. “The Crooked Timber of Mankind”. In: A. O. Rorty; J. Schmidt, (eds) (2009), pp. 129-149. 
HERDER, J. G. Ideen zur Philosophie der Geschichte der Menschbeit, 1784. Repr. Wesbaden: Vourier Verlag, 1985.

HÖFFE, O. Königliche Völker: zu Kants kosmopolitischer Rechtsund Friedenstheorie. Frankfurt am Main: Suhrkamp, 2001.

- (Hrsg.) Immanuel Kant. Schriften zur Geschichtsphilosophie. Berlin: Akademie Verlag, 2011.

- (Hrsg.) Immanuel Kant. Zum ewigen Frieden. Berlin: Akademie Verlag, 2004.

KANT, I. Gesammelte Schriften. Hrsg.: Bd. pp. 1-22 Preussische Akademie der Wissenschaften, Bd. 23 Deutsche Akademie der Wissenschaften zu Berlin, ab Bd. 24 Akademie der Wissenschaften zu Göttingen. Berlin, 1900ff.

. Anthropologie in pragmatischer Hinsicht. (Anth) Trad. Clélia Aparecida Martins. São Paulo: Iluminuras, 2006.

- Ende aller Dinge. (EaD) Trad. Artur Morão. Lisboa: Edições 70, 1993.

. Der Streit der Fakultäten. (SF) Trad. Artur Morão. Lisboa: Edições 70, 1993.

. Die Metaphysik der Sitten. (MS) Trad. José Lamego. Lisboa: Calouste Gulbenkian, 2005.

. Die Religion innerhalb der Grenzen der bloßen Vernunft. (RGV) Trad. Artur Morão. Lisboa: Edições 70, 1992. 
. "Idee zu einer allgemeinen Geschichte in weltbürgerlicher Absicht”. (IaG) Trad. Artur Morão. In: A paz perpétua e outros opúsculos. Lisboa: Edições 70, (2004).

- Kritik der praktischen Vernunft. (KpV) Trad. Valerio Rohden. São Paulo: Martins Fontes, 2002.

. Kritik der Urteilskraft. (KU) Trad.Valerio Rohden e António Marques. 2.ed. Rio de Janeiro: Forense Universitária, 2002.

. Muthmaßlicher Anfang der Menchengeschichte. (MAM) Trad. Joel Thiago Klein. In: Ethic@, v.8, n.1, (2009), pp. 157-168.

. Pädagogik. (Päd) Trad. Francisco Cock Fontanella. 4.ed. Piracicaba: UNIMEP, 2004.

- Recensionen von I. G. Herders Ideen zur Philosophie der Geschichte der Menschheit. Theil 1. 2. (RezHerder).

. Reflexionen zur Antbropologie. (Refl) Bd. 15.

. Reflexionen zur Moralphilosophie. (Refl) Bd. 19.

. "Über den Gemeinspruch: Das mag in der Theorie richtig sein, taugt aber nicht für die Praxis". (TP) Trad. Artur Morão. In: A paz perpétua e outros opúsculos. Lisboa: Edições 70, (2004).

. Vorlesungen über Moralphilosophie. (Vo-Mo/Collins) Bd. 27.

Manuscrito - Rev. Int. Fil., Campinas, v. 37 , n. 1, p. 165 - 221, jan.-jun. 2014. 
. "Was heißt: Sich im Denken Orientiren?" (WDO) Trad. Artur Morão. In: A paz perpétua e outros opúsculos. Lisboa: Edições 70, (2004).

. "Zum ewigen Frieden". (ZeF) Trad. Artur Morão. In: A paz perpétua e outros opúsculos. Lisboa: Edições 70, (2004).

KLEIN, J. "A sociabilidade insociável e a antropologia kantiana". In. Revista de Filosofia: Aurora, v. 25, (2013a), pp. 265-285.

. “Kant sobre o progresso na história”. In: Ethic@ (UFSC), v. 12, (2013b), pp. 67-100.

. "Die Weltgeschichte im Kontext der Kritik der Urteilskraft." In. Kant-Studien, v. 104, (2013c), pp. 188-212.

LUDWIG, B. “Will die Natur unwidersteblich die Republik? Einige Reflexionen anlässlich einer rätselhaften Textpassage in Kants Friedensschrift". In: Kant-Studien, n. 88, (1997), pp. 218-228.

- "Bemerkungen zum Kommentar Brandts? Will die Natur unwiderstehlich die Republik?” In: Kant-Studien, n.89, (1998), pp. 80-83.

NIESEN, P. "Volk-von-Teufel-Republicanismus. Zur Frage nach den moralischen Ressourcen der liberalen Demokratie". In: L. Wingert; K. Günther, (Hrgs) (2001) pp. 568-604.

PINZANI, A. An den Wurzeln moderner Demokratie: Bürger und Staat in der Neuzeit. Berlin: Akademie Verlag GmbH, 2009.

Manuscrito - Rev. Int. Fil., Campinas, v. 37 , n. 1, p. 165 - 221, jan.jun. 2014. 
. "Botanische Antropologie und physikalische Staatslebre: zum Fünften und Sechsten Satz der Idee”. In: O. Höffe, (Hrsg.) (2011) pp. 63-78.

REHBERG, A. W. “Über das Verhältnis der Theorie zur Praxis”, 1793. Repr. in D. Henrich, (Hrsg). Kant, Gentz, Rebberg: Über theorie und Praxis. Frankfurt: Suhrkamp Verlag, (1967).

RORTY, A. O.; SCHMIDT, J. (Eds.). Kant's Idea for a Universal History with a Cosmopolitan Aim. Cambridge: Cambridge University Press, 2009.

SANTOS, L. R. dos; ANDRÉ, J. G. (Cords.). Filosofia Kantiana do Direito e da Política (Seminário Internacional). Lisboa: Centro de Filosofia da Universidade de Lisboa, 2007.

WILLASCHEK, M. "Recht obne Ethik? Kant über die Gründe, das Recht nicht zu brechen”. In: V. Gerhardt (Hrsg.) (2005), pp. 188-203.

WINGERT, L.; GÜNTHER, K. (Hrgs). Die Öffentlichkeit der Vernunft und die Vernunft der Öffentlichkeit. Frankfurt am Main: Suhrkamp, 2001. 